\title{
A CONTEMPORANEIDADE DO INFERNO ILUSTRADO DE BARLOWE
}

\author{
THE ACTUALITY OF BARLOWE'S ILLUSTRATED INFERNO \\ Sérgio Rizo
}

Professor do Departamento de Arquitetura e Urbanismo da Universidade de Brasília - UnB.

\begin{abstract}
RESUMO
O objetivo desse artigo, num primeiro momento, é mostrar que o organismo metamórfico vivo imaginado por Wayne Barlowe, um ilustrador contemporâneo norte-americano, como a paisagem do seu Inferno ilustrado, é na verdade o imensurável corpo do Demônio. Num segundo momento, pretendo mostrar que a consciência agônica demoníaca é o reflexo do drama da existência humana. O tema principal do artigo será, portanto, a representação dos corpos, tanto dos demônios quanto dos danados, e a sua relação com os espaços no Inferno ilustrado de Wayne Barlowe.
\end{abstract}

Palavras-Chave: História; Inferno; Corpo; Idade Média; Renascimento; Wayne Barlowe.

\begin{abstract}
The purpose of this article, at the outset, is to show that the living metamorphic organism imagined by Wayne Barlowe, a contemporary American illustrator, as a landscape of his illustration of Hell, is actually the gigantic body of the Devil. In a second moment, I intend to show that this demonic agonizing consciousness is the reflection of the drama of human existence. The main theme of the article will thus be the representation of the bodies, both of the demons and of the damned, and their relation to the spaces in the illustrated Inferno of Wayne Barlowe.

Key Words: History; Hell; Body; Middle Ages; Renaissance; Wayne Barlowe.
\end{abstract}

\section{Wayne Douglas Barlowe: formação}

Wayne Douglas Barlowe é um ilustrador norteamericano contemporâneo, com notória experiência no campo da ilustração de ficção científica. Bem conhecido dos leitores norte-americanos do gênero, nasceu em Glen Cove, Nova York, em 1958. Na sua formação inicial, relativa à grade school americana (escola de primeiro grau no Brasil), os seus variados interesses em biologia, arqueologia e paleontologia evidenciaram-se nos desenhos feitos nos seus cadernos escolares. Posteriormente, ele passou a dar atenção aos paperbacks (livros de preço módico) de ficção científica e histórias fantásticas, por encorajamento do pai, que comprou o seu primeiro livro do gênero de fantasia intitulado $A$ Princesa de Marte. A partir daí, orientou sua trajetória como um artista do fantástico e da fantasia, especialmente como ilustrador de ficção científica.

${ }^{1}$ Barlowe, Wayne. The Alien Life of Wayne Barlowe, Morpheus International, Beverly Hills, CA. P.6.
Os pais de Barlowe, Sy e Dorothea Barlowe, são consagrados ilustradores de história natural e sempre representaram uma fonte de constante apoio e inspiração na sua carreira. A importância dos pais é afirmada pelo próprio Barlowe, quando relembra a sua formação na introdução do seu livro The Alien Life of Wayne Barlowe ${ }^{1}$ :

(...) aquele lugar de maravilhas dois andares abaixo - o estúdio dos meus pais, lugar lotado de livros de ciências naturais e espécies marinhas engarrafadas, bem como de pilhas de ilustrações científicas sobre as quais eu me debruçava. Como meus pais eram ilustradores científicos muito requisitados, estavam sempre envolvidos em projetos longos. Eu passei muitas horas no estúdio deles, nos dias de chuva, observando livros de dinossauros ou nas suas pranchetas, absorvendo a atmosfera criativa de um estúdio de ilustração. Lá, aprendi a maneira científica de pensar e a importância da exatidão. Também aprendi a amar a Natureza e os animais. Aqueles dias no estúdio dos meus pais constituem memórias muito agradáveis. Eles me fizeram o que eu sou hoje e não posso me imaginar numa outra vida senão naquela de um estúdio de ilustração. 
Essas primeiras e importantes influências delinearam na personalidade de Barlowe, não somente uma convergência de natureza técnica com o trabalho dos seus pais, mas uma identificação de ordem eminentemente temática, relacionada com o seu notável interesse pelo campo da ilustração científica. Acrescentese a isso o fato de que, recentemente, Barlowe têm se dedicado a projetos de longa duração, tal qual seus pais fizeram, que são os seus livros de criação própria. Tais projetos envolvem a elaboração de livros nos quais ele se incumbe das etapas de concepção e execução, incluindo tanto as ilustrações quanto o texto. Dois deles ${ }^{2}$, referentes às versões do seu inferno, são os objetos centrais desse artigo.

O aspecto mais específico do aprendizado em arte de Barlowe iniciou-se quando ele frequentou a Art Students League de Nova York em 1973. A League é uma sociedade cooperativa e independente de artistas e estudantes, que tem por objetivo incentivar, de maneira informal, o ensino e a prática das belas artes ao público interessado. A Liga caracteriza-se pela informalidade e abertura da sua estrutura de cursos de belas artes, que conta com as áreas de desenho, pintura, gravura e escultura. Os instrutores, artistas profissionais de reputação nacional, desenvolvem seus próprios métodos e ideias sem a interferência direta da administração. Os estudantes são livres para escolher entre vários modos de expressão, do realismo ao abstracionismo. Muitos artistas famosos no mundo todo foram instrutores, palestrantes e estudantes na League, como Georgia O'Keeffe, Thomas Hart Benton, Alexander Calder, Hans Hofmann e Jackson Pollock.

As classes de modelos vivos continuam sendo as atividades mais características da League. Em termos históricos, elas foram o motivo da sua própria existência, pois a League surgiu em 1875, como uma alternativa às classes de modelos vivos que eram oferecidas somente pela tradicional National Academy of Design. Um dos instrutores expoentes da liga em anatomia e desenho da figura humana foi Robert Beverly Hale, com diversos livros publicados, que ainda hoje, recebem significativa acolhida pelo público interessado nas artes plásticas. A League sempre foi e continua a ser uma sociedade cooperativa (um terço do conselho diretor é formado por estudantes) baseada na ajuda mútua entre os seus membros. Nunca foram emitidos diplomas formais (são fornecidos certificados de atendimento dependendo da participação dos estudantes) e nem existe um currículo fixo; basta que a pessoa lá esteja pelo simples amor à arte e pela vontade de trocar ideias.

Barlowe deu seguimento à sua formação em arte entrando para a Cooper Union em 1976. The Cooper
Union for the Advancement of Science and Art, estabelecida em 1859, está entre as mais antigas e distintas instituições de ensino avançado dos Estados Unidos. A escola é o legado de Peter Cooper, industrial, inventor, milionário e quem desenhou e construiu o primeiro motor a vapor para ferrovia da América. É a única escola privada e com bolsas de estudo integrais, que é dedicada exclusivamente ao preparo de estudantes para as profissões da arquitetura, arte e engenharia, nos Estados Unidos.

Entretanto, a experiência de aprendizado de Barlowe na Cooper Union não foi satisfatória, pois segundo suas próprias palavras ${ }^{3}$ :

O período em que estudei na Cooper Union foi um tempo conflituoso. Frequentei a escola por dois anos e, embora reconheça que aprendi algumas boas coisas lá, não posso dizer que lamentei ter saído mais cedo. Descobri que para alguém que tinha uma ideia clara da carreira a seguir, como eu, a escola tinha uma visão deturpada da ilustração.

Ele estudou dois anos na Cooper Union e abandonou o curso por discordar da relutância dos instrutores em incluir princípios da ilustração nas suas discussões. Barlowe sempre considerou a ilustração como um nobre ofício, com uma rica e qualitativa tradição de excelentes artistas. É oportuno lembrar que, hoje em dia, o contexto em que é feita uma ilustração pode diferir consideravelmente daquele em que é feita uma pintura.

No sentido genérico, ilustração é a representação de material informativo em livros, revistas e jornais, que tem por fim, através da utilização de uma imagem visual, tornar claro ou demonstrar um conteúdo do texto, ou ainda, dar vivacidade e aspecto concreto aos personagens e incidentes de uma estória. Há um compromisso específico com a imagem trabalhada, em termos inclusive do prazo de execução. Já na pintura, a obrigação na elaboração da imagem é tão somente com o desejo do artista, com a expressão da sua vontade. Independe, por princípio, de uma solicitação exterior. Contudo, visto que os elementos de ordem estética, como formas, linhas, cores, proporções e composição, são comuns tanto à ilustração quanto à pintura, existe uma convergência de meios nessas duas formas de representar imagens.

A frustração de Barlowe, então, pode ser mais bem compreendida nestes termos. Ainda mais ao se considerar que as pinturas do passado foram executadas por encomenda e com finalidades

${ }^{2}$ Barlowe's Inferno, Beverly Hills, Morpheus International, 1998 e Brushfire. Illuminations from the Inferno, Beverly Hills, Morpheus International, 2001.

${ }^{3}$ Barlowe, Wayne. The Alien Life of Wayne Barlowe, Morpheus International. Beverly Hills, CA, 1995. P.6. 
ilustrativas ${ }^{4}$. E muitas, hoje em dia, ainda o são. Portanto, às vezes é muito difícil fazer a distinção entre uma pintura e uma ilustração, quando não desnecessário. De qualquer modo, e de acordo com as palavras de Barlowe, não era assim que pensavam os instrutores da Cooper Union.

Em compensação, no mesmo ano em que ingressou na Cooper Union, Barlowe foi contratado como estagiário no Departamento de Exposições do American Museum of Natural History, instituição para a qual seus pais já haviam trabalhado. A experiência provou ser profícua, pois Barlowe teve a chance de estar diretamente em contato com o mundo da paleontologia e dos dinossauros que tanto admirava, quando ainda criança, nos livros do estúdio de seus pais.

Após abandonar o curso na Cooper Union, Barlowe se viu envolvido com o projeto de ilustrar o pop-up book de Star Wars, naturalmente por intermédio dos contatos e amizades profissionais de seus pais. Deu início, então, a sua carreira de ilustrador profissional.

\section{A obra de Barlowe}

Nova York, uma das principais e mais populosas cidades dos Estados Unidos, tem um amplo e diversificado setor gráfico de edição, publicação e distribuição de livros e revistas. A ilustração de livros encontra na cidade um vasto e concorrido mercado de trabalho. Foi ao inserir-se neste contexto que Barlowe deu seus primeiros passos como ilustrador profissional. 0 seu envolvimento com projetos maiores e autônomos, de ilustrações completas de livros inteiros, demonstrou ter sido gradativo.

${ }^{4}$ As pinturas que representavam temas da Bíblia e que só podiam ser plenamente compreendidas por aqueles que tivessem familiaridade com as fontes literárias, por exemplo, no século XV, quando a maior parte das pinturas é religiosa. De acordo com Michael Baxandall, no seu livro O Olhar

Renascente: Pintura e Experiência Social na Itália da Renascença, Paz e Terra, São Paulo, 1991, pág.48:

"O que isso significa, num sentido restrito, é evidente, mas por 'pinturas religiosas' deve-se entender mais que um certo conjunto de temas; significa que as pinturas eram criadas para preencher fins institucionais precisos, que sustentavam as atividades espirituais e intelectuais e que dependiam também da jurisdição de uma teoria eclesiástica consolidada com relação às imagens".

${ }^{5}$ Pop-up books são aqueles livros, geralmente destinados aos leitores infanto-juvenis, em que existe um encarte dobrável que se monta ao abrir-se a página, formando um cenário com figuras, na maioria das vezes.

${ }^{6}$ Pelo menos é o que Barlowe declara na sua entrevista à revista Starlog, fascículo 259, fevereiro de 1999, página 44.

${ }^{7}$ BARLOWE, Wayne in The Alien Life of Wayne Barlowe, pág. 7.

${ }^{8} \mathrm{O}$ prefácio do livro é de Ian Summers e de Beth Meachan, dois editores que dividem a apresentação do livro com

Barlowe.

${ }^{9}$ The Alien Life of Wayne Barlowe, p.7.

${ }^{10}$ Expedição.
A primeira oportunidade se fez pela encomenda do popup book ${ }^{5}$ de Star Wars em 1978, data, também, da sua publicação. Na ocasião, ele tinha apenas 19 anos de idade e como experiência profissional, pouco mais de seis capas de paperbacks, além de ter colorido um livro sobre insetos num trabalho em conjunto com seus pais. Não obstante, e muito provavelmente pela indicação dos seus pais ${ }^{6}$, ele entrou em contato com o diretor de arte da editora Random House, que o contratou para o trabalho. A tarefa envolveu o máximo de fidelidade ao material enviado pela Lucasfilm (empresa pertencente ao cineasta George Lucas, responsável pela película de Star Wars), e Barlowe teve de elaborar as ilustrações na mesa de pingue-pongue da família, único local grande o suficiente para o manejo dos encartes. A experiência provou ser, segundo suas próprias palavras, "uma incrível introdução ao mundo dos livros"7. E serviu, também, para abrir as portas do seu projeto posterior, cuja concepção foi de sua autoria, conforme veremos a seguir.

O primeiro livro idealizado por Barlowe, intitulado Barlowe's Guide to Extraterrestrials, foi publicado em 1979 pela editora Workman Publishing. O livro, que teve a coautoria de Barlowe $^{8}$ e que foi por ele concebido e ilustrado, foi escolhido como o Melhor Livro Ilustrado de 1979 pela Locus poll, e também como o Melhor Livro para Jovens, pela Sociedade Bibliotecária Americana. Existem mais de 250.000 cópias do Guia impressas atualmente, e uma edição japonesa foi recentemente posta no mercado. O livro foi ainda indicado para o prestigiado Hugo Award pela American Book Award e pela comunidade de ficção científica. Nesse guia de extraterrestres, já considerado um clássico no gênero, Barlowe retrata 50 alienígenas da literatura popular de ficção cientifica, de autores como Larry Niven, Arthur C. Clark, Frank Herbert, Robert Silverberg, entre outros. As ilustrações mostram humanoides, insetos fantásticos, seres reptilianos, formas viventes protoplasmáticas, gasosas e cristalinas, todas descritas num estilo de ilustração detalhado e naturalista. De acordo com o testemunho de Barlowe, ${ }^{9}$ "O guia foi uma expressão natural do meu interesse pela história natural. Foi uma forma de misturar ficção científica e natureza, de misturar o mundo dos meus pais com o meu, e que provou ser uma mistura bastante popular".

O seu segundo livro, intitulado Expedition ${ }^{10}$, também editado pela Workman em 1990, foi totalmente concebido, escrito e ilustrado por Barlowe. Esse trabalho foi votado como o Melhor Livro para Adolescentes de 1991 pela Biblioteca Pública de New York, além de ter sido indicado para o Chesley Award de 1991, pela Associação dos Artistas de Ficção Científica. O livro, do gênero de ficção científica, trata de uma jornada imaginária ao planeta denominado de 
Darwin IV, realizada no ano de 2355. Barlowe levou perto de cinco, anos para escrevê-lo e ilustrá-lo. Sobre isso, disse ele, na entrevista constante na revista mensal de ficção científica Starlog ${ }^{11}$ :

Expedição foi uma incursão fictícia de história natural a um planeta alienígena, escrita num estilo jornalístico e semelhante às observações constantes nos trabalhos de Charles Darwin. É de natureza descritiva e relata as vistas e eventos ocorridos durante a expedição a esse planeta. Expedição foi uma tentativa de criar um novo mundo e ao mesmo tempo de oferecer ao público uma nova categoria de dinossauros. Os animais imaginados têm o mesmo apelo: são gigantescos, predadores e possuem tudo aquilo que o público gosta com relação aos dinossauros.

O texto é relatado na primeira pessoa, o próprio Barlowe, que assume uma personagem amante da natureza e que trabalha como ilustrador da vida selvagem. Seu personagem é saudoso de um planeta outrora belo e vivo, mas que se torna poluído e quase desprovido de vida animal pelo descaso histórico e acumulado da raça humana na conservação da natureza. A Humanidade tem sido ajudada a mais de cem anos por uma civilização extraterrestre, os Yma, que por amor a todas as formas de vida, resolveram ensinar aos terráqueos como reparar os danos feitos ao seu planeta mediante o acordo de 2231. Com a descoberta do sistema binário de seis planetas Darwin IV, os Yma tencionam explorar essa nova região do espaço. Barlowe é, então, contratado para ilustrar as formas de vida existentes em Darwin IV, integrando uma equipe de pesquisadores, composta de cientistas e técnicos, que para lá se deslocam. O toque irônico da situação é que Barlowe é escolhido pelos Yma para que o seu trabalho resulte numa impressão mais subjetiva e atmosférica, do que as convencionais fotografias holográficas de alta tecnologia. O livro descreve, a partir daí, os variados e fantásticos ecossistemas existentes em Darwin IV, com especial relevo às diversas espécies animais do planeta. A fauna de Darwin IV evoluiu para um gigantismo acentuado devido à baixa gravidade do planeta, que por ser menor que a Terra, tem apenas $0.6 \mathrm{~g}$ desta.

Existem no livro dois aspectos de especial interesse para este artigo: $\mathrm{mm}$ é relativo ao Mar Amebiano, uma bizarra região coberta por um organismo gelatinoso de $10 \mathrm{~m}$ de espessura, espalhado por quase $5 \%$ da superfície de Darwin IV. A identificação desse organismo, enquanto um corpo animal, com um elemento da paisagem, no caso o mar, remete as questões das metáforas corporais e do animismo, temas fundamentais no estudo da relação simbólica do corpo com a paisagem.
O outro diz respeito aos enormes animais denominados Sea Striders ${ }^{12}$ que, segundo Barlowe, assumem proporções de Behemot, o gigantesco animal bíblico (conforme o livro de Jó, 40-10). O fenômeno do gigantismo é uma característica simbólica presente em variadas mitologias (como, por exemplo, a gigantomaquia - luta de Zeus contra os gigantes, da mitologia grega), além da cristã, sendo associado comumente à instância divina. A questão do gigantismo é fundamental na argumentação da corporeidade do Inferno de Barlowe.

A título de curiosidade menciona-se o fato da ausência de aparelhos óticos na fauna de Darwin IV, ou seja, os animais desse planeta são desprovidos do sentido da visão, substituindo-o por sistemas orgânicos sensíveis ao infravermelho e com desempenho semelhante aos dos aparelhos de sonar.

O livro de Barlowe intitulado de The Alien Life of Wayne Barlowe, foi publicado em 1995 pela Morpheus International. Com prefácio de Vincent Di Fate, um também ilustrador amigo, o livro foi escrito por Barlowe e fez um resumo ilustrado da sua carreira, até então. Suas ilustrações estão divididas em três capítulos, contendo, respectivamente, as Primeiras Ilustrações e os Trabalhos de Encomenda, as Ilustrações de Dinossauros e, por último, o dos Projetos, que se divide nos projetos de Thype, Expedition, Future Man e Inferno. Dos assuntos de valia para este artigo, menciona-se as ilustrações mostradas no capítulo das obras encomendadas, relativas ao Leviatã e a Black Easter.

No caso do Leviatã, a pintura foi feita simplesmente no sentido de ocupar o espaço do fundo do estúdio de Barlowe para uma entrevista concedida ao jornal Newsday. Em termos da imagem, consta uma cabeçorra de uma espécie de dragão, a fera bíblica chamada de Leviatã, que de acordo com o constante na Bíblia, no livro de Jó, 40-20, parece ter designado o crocodilo do Nilo. Inicialmente, Barlowe a descreve como tendo sido a mistura de um cetáceo com um humano. Pouco depois, quando a noção bíblica de Satã, a serpente, lhe veio à mente, todo o resto da ilustração assumiu um sentido diabólico mais evidente. Ressaltase a escala gigantesca com que a besta foi concebida, acentuada pelas partes de minúsculos esqueletos humanos incrustados nos tijolos que compõe a parede do fundo da ilustração. Barlowe nos diz que se passaram anos até que a verdade por detrás dessa ilustração Ihe fosse revelada. Foi somente quando ele

\footnotetext{
${ }^{11}$ Starlog é uma revista mensal de ficção científica editada pelo Starlog Group, New York. A entrevista é constante nas páginas 43-46, do número 259 de fevereiro de 1999.

${ }^{12}$ Animais que andam pelo mar a passos largos.
} 
começou as pesquisas preliminares de $A$ Pilgrimage to Hell ${ }^{13}$ que tomou consciência do que havia feito. Ele nos informa ter havido uma estranha coincidência entre aquilo que ele pensou ter selecionado ao acaso entre diversos elementos visuais, e a figura mítica cristã do anjo caído chamada de Leviatã, a grande serpente torcida do mar, constante na Bíblia, em Isaías, 27,1.

No mesmo capítulo de Primeiras Ilustrações, constam os trabalhos que Barlowe elaborou para ilustrar dois livros de James Blish ${ }^{14}$, Black Easter ${ }^{15}$ e Day after Judgement ${ }^{16}$. Os livros, que anteriormente compunham um só volume, fazem parte de um grupo de contos que, segundo Blish, formam uma trilogia, cada um abordando um aspecto diferente do preço que se paga para se ter o Conhecimento. O primeiro livro da série de contos, anterior aos dois citados, foi $A$ Case of Conscience $^{17}$, ganhador do Hugo Award de 1959. O livro é sobre o confronto entre um jesuíta e uma raça inteligente alienígena, em que o religioso conclui tratarse de uma farsa satânica. O segundo livro da série de contos foi Dr. Mirabilis, que Barlowe também teve a oportunidade de ilustrar, conforme consta na ilustração da página 18 do The Alien Life of Wayne Barlowe. O personagem de Mirabilis foi baseado na vida do filósofo e cientista Roger Bacon ${ }^{18}$. A ilustração mostra o personagem, em hábito franciscano entre os dois símbolos da teologia, o Bem (representado por um anjo) e o Mal (representado por um monstro alado semelhante a um dragão). Tal procedimento buscou expressar os conflitos pessoais e a controvérsia teológica pela qual passou Dr. Mirabilis, visto que ele foi um desafiador dos intelectos da sua época, desenvolvendo conceitos científicos inovadores relacionados à natureza, alquimia, astronomia e ao modo pelo qual o mundo funcionava.

O terceiro livro da série tinha dois contos mais curtos, sendo o primeiro intitulado Black Easter e o segundo The Day after Judgement. Quando Barlowe recebeu a encomenda de elaborar as ilustrações sobre os contos

${ }^{13} \mathrm{O}$ título, que traduzido para o português seria Uma Peregrinação ao Inferno, refere-se ao projeto maior inicial de Barlowe, ainda em andamento, de realizar um livro sobre o inferno, do qual o Barlowe's Inferno e Brushfire são uma parte.

14James Benjamin Blish, 1921 - 1975, renomado escritor norte-americano do gênero ficção cientifica e fantasia. É bastante conhecido como o autor das novelas referentes ao famoso seriado de TV Jornada nas Estrelas.

${ }^{15}$ Páscoa Negra.

${ }^{16}$ O Dia Após o Juízo Final.

${ }^{17}$ Uma Questão de Consciência.

${ }^{18}$ Roger Bacon (1214 - 1294), também conhecido como Doutor Mirabilis (que em latim significa professor maravilhoso) foi um filosofo inglês, religioso da ordem dos franciscanos, que enfatizou consideravelmente o empirismo e é tido como um dos precursores do método científico.

${ }^{19}$ The Alien Life of Wayne Barlowe, página 36. de Blish, a orientação foi para que ele concebesse uma só capa que pudesse ser utilizada para dois livros, já que seria feito um livro para cada conto, separadamente. No primeiro conto, Black Easter, um rico fabricante de armas faz um estranho pedido a um necromante: ele queria a libertação de todos os demônios do Inferno, por uma noite apenas, para ver o que iria acontecer. O livro consiste, basicamente, na longa descrição do ritual de evocação e das figuras grotescas dos demônios na medida em que eles aparecem. O livro termina com a declaração de um dos demônios, Baphomet, que informa ser impossível o retorno dos demônios ao Inferno, pois finda a guerra, Deus estava morto. O segundo conto, The Day after Jugdement, é uma continuação do primeiro, pois tem os mesmos personagens. Mostra que, afinal de contas, Deus poderia não estar morto, pois alguém estava restringindo as ações dos demônios na Terra.

O segundo capítulo do livro Alien Life of Wayne Barlowe é dedicado as suas ilustrações de dinossauros. Barlowe começou a pintar dinossauros em 1991, o que, posteriormente, resultou em muitas encomendas. Sua primeira ilustração impressa de um dinossauro foi editada pela Scheele Fine Arts em 1993. O primeiro livro de ilustrações de dinossauros feito por Barlowe foi publicado em 1995 pela Scholastic Books. Este livro foi escrito pelo renomado paleontólogo Dr. Peter Dodson e teve grande receptividade pelos leitores. Os dinossauros têm sido uma temática predileta ao longo da carreira de Barlowe, combinando a sua inclinação para o fantástico com a formação em história natural. Nas suas próprias palavras, Barlowe nos conta ${ }^{19}$ :

Pintar dinossauros, para mim, é aquilo que mais se aproxima de uma viagem no tempo. Como todo bom artista de paleontologia atestaria, não se pode fazer esse tipo de trabalho sem tentar, de olhos fechados, imaginarse no período mesozoico. Sentir o cheiro do ar de um outro mundo em outro tempo, proveniente dos vapores da vegetação apodrecida e dos seus organismos vivos. Deve-se ouvir o incessante barulho dos insetos, o bater de asas dos pterossauros, a respiração pesada de uma enorme criatura a se alimentar de plantas gigantescas. E deve-se sentir também, o calor dos raios de um novo sol, mais quente. Como acontece em qualquer outro tipo de arte, o artista deve ter um senso inato do seu tema, deve haver uma considerável imersão e identificação de sua parte com o assunto representado.

É interessante observar, do ponto de vista técnico, que algumas de suas ilustrações de dinossauros são bastante detalhadas, levando cerca de dois meses na sua execução, como foi o caso da ilustração Jurassic Siesta, constante na página 32 do Alien life of Wayne Barlowe. Esse apego ao realismo da ilustração, que deve ser principalmente convincente, é o reflexo de uma tendência acentuadamente racionalista na arte de 
Barlowe. Ele procura uma base de trabalho que se relacione, o quanto possível, com o campo da ilustração de história natural. A esse respeito ele diz que "Minha imaginação trabalha de um modo bem linear: uma ilustração deve ser convincente para mim, antes que eu a mostre para outras pessoas ${ }^{\prime 20}$.

O terceiro e último capítulo do The Alien Life of Wayne Barlowe, denominado de Projetos, inclui os projetos de Thype, Expedition, Future Man e Inferno. Thype é o nome de uma personagem que Barlowe criou de livre iniciativa e que remonta ao seu tempo de estudos na Cooper Union. Ele é um alienígena, espadachim e peregrino, um compósito de partes de variados animais, que se vê envolvido, tanto numa jornada interior, quanto numa aventura exteriormente concreta, através de um panorama bizarro, um mundo chamado de Vaspar. No entanto, o livro de Thype permanece, até então, apenas como um projeto, com alguns estudos realizados e com poucas ilustrações executadas. Barlowe declarou ter achado a personagem, no final das contas, um tanto convencional, pois. embora tenha sido concebida como um alienígena, possuía características demasiadamente terrestres. Barlowe considera aproveitar sua criação para um jogo de vídeo game ou quadrinhos. Entretanto, existe uma ilustração interessante como exemplo para os temas do gigantismo e das metáforas corporais, a serem discutidos no decorrer do artigo, que está na página 44 e intitula-se Thype and the Villar. A raça nômade chamada de Villar, que Thype encontra nas suas aventuras, constitui-se de seres enormes, andarilhos, de natureza guerreira e de corpos semelhantes aos dos homens até a cintura. A partir daí, e principalmente por sobre os ombros, erguem-se verdadeiros castelos medievais de pedra com elementos arquitetônicos, tanto mouros quanto cristãos. Em outras palavras, os Villar são de fato cidadelas andantes, que têm escondidos no seu interior, dentro de alguma sala escura e recolhida, os seus verdadeiros habitantes: seres do tamanho dos homens, que os controlam como se fossem árabes montando camelos. A relação metafórica entre o corpo e o castelo é evidente e vai merecer um estudo mais detalhado no desenvolver da tese, onde serão analisadas outras representações semelhantes e constantes do inferno de Barlowe.

O segundo projeto incluso nesse capítulo é relativo às ilustrações do seu livro Expedition, que já foi explicado anteriormente, podendo-se avançar para o seu terceiro projeto, Future Man $^{21}$, sobre o qual nos informa Barlowe que:
Esses desenhos preliminares foram criados como parte de uma proposta para um projeto de um livro em 1984. O livro iria tratar, de forma quase que científica, das possibilidades evolutivas da raça humana num futuro distante. Infelizmente, o livro nunca poderá ser editado, visto que os seus estudos foram plagiados e utilizados no trabalho de um outro autor.

Embora conste de somente uma página ilustrada do livro e nunca vá ser publicado, esse projeto interessa para ilustrar um ponto importante que a tese irá abordar, referente às metamorfoses que os corpos sofrem na representação do Inferno de Barlowe. O projeto do Future Man mostra três adaptações evolutivas de seres humanos que são o Homo Aquaticus, o Homo Deserticulus e um terceiro sem denominação, que vivem, respectivamente, em três diferentes ambientes climáticos, o mar, o deserto e a região glacial. Apesar de esses seres manterem, em termos da sua aparência, a identidade básica da estrutura humana, seus corpos são a evidência de um acentuado processo de mutação genética, decorrente de sucessivas adaptações evolutivas ao meio ambiente. A idéia do projeto, de características científicas, cria aberrações bastante similares aos monstros do romance de H. G, Wells, escrito em 1896 e chamado de "A Ilha do Dr. Moreau"22.

O romance é uma parábola da teoria da evolução de Darwin, onde os animais progressivamente assumem algumas características humanas. A intenção de Barlowe, no entanto, parece ser na direção contrária, pois suas criações assumem uma progressiva animalização na sua adaptação ao meio ambiente hostil. Um exemplo claro é a ênfase dada na representação dos caninos proeminentes, no estudo das mandíbulas do Homo Deserticulus. É de se notar a ânsia da precisão científica de Barlowe na concepção das mudanças que o corpo humano sofreria na sua futura adaptação aos ambientes citados. $\mathrm{O}$ ato de imaginar as suas criaturas de modo científico irá influenciar toda a iconografia dos demônios ilustrados no seu Inferno. As mutações genéticas, enquanto matérias-primas do imaginário, são o equivalente atual do fenômeno histórico da metamorfose, reflexo do persistente desejo do homem, na compreensão das questões relativas aos processos de transformação do corpo.

O último projeto constante no Alien Life of Wayne Barlowe é relativo ao Inferno, que é a temática central do artigo. O terceiro livro de Barlowe, intitulado

\footnotetext{
${ }^{20}$ Revista mensal Starlog, número 259, fevereiro 1999, página 43.

${ }^{21} \mathrm{O}$ Homem do Futuro.

${ }^{22}$ Herbert George Wells, 1886-1946, escritor inglês de literatura fantástica e de ficção científica, popularmente conhecido também pela autoria da Máquina do Tempo, 0 Homem Invisível e a Guerra dos Mundos.
} 
Barlowe's Guide to Fantasy ${ }^{23}$ foi publicado em 1996 pela Harper Collins, N.Y. O livro contém cinqüenta ilustrações de criaturas e personagens fantásticas de contos populares de ficção científica, incluindo-se unicórnios, dragões, etc, de autores principalmente contemporâneos, como Peter S. Beagle, Robert Jordan, Clive Barker, Marion Zimmer Bradley e H. P. Lovecraft.

Os trabalhos de Barlowe têm sido publicados em mais de trezentas capas de revistas e livros dos maiores editores. Ele também criou ilustrações para as revistas Life, Time e Newsweek. Seus trabalhos têm sido exibidos em programas de televisão como o Universo, de Walter Cronkite, e Sábado à Noite de Connie Nhung. Foi exibida, recentemente, uma entrevista com Barlowe no programa Dentro do Espaço, do canal de ficçãocientífica Sci-Fi. Barlowe têm produzido itens bastante diversificados, desde livros de encartes articulados (popup books), contos ilustrados e até calendários.

Sua linha de bonecos de ficção-cientifica denominados The Powerlords ${ }^{24}$, foi manufaturada pela Revell em 1983.

Suas pinturas foram exibidas no Museu de Artes do Bronx, no Centro de Ciências de Orlando, no New Britain Museum of American Art, na Sociedade dos Ilustradores de New York, no The Atrium de Park Avenue, no Discovery Museum de Brigdeport em Connecticut, e no Planetário Hayden. Ele foi o organizador, em 1984, da primeira exposição de arte do gênero ficção-científica na história da Sociedade dos Ilustradores.

\subsection{O Inferno ilustrado de Barlowe}

Os livros de autoria de Barlowe que servem como fontes primárias para minha pesquisa são: Barlowe's Inferno ${ }^{25}$ e Brushfire: Illuminations from the Inferno ${ }^{26}$. O exemplar do Barlowe's Inferno que utilizo é uma primeira edição publicada pela Galerie Morpheus International, Inc., Beverly Hills, CA, em 1998. O livro tem 72 páginas, 29 ilustrações, capa dura e impressão colorida. A concepção gráfica, as ilustrações e o texto são de autoria de Barlowe.

O projeto gráfico do livro mostra páginas de fundo negro na quase totalidade da edição. As exceções são, além das duas contracapas, as cinco páginas iniciais de

\footnotetext{
${ }^{23}$ O Guia da Fantasia do Barlowe.

${ }^{24}$ Os Senhores do Poder.

${ }^{25}$ BARLOWE, Wayne. Barlowe's Inferno, Beverly Hills, Galerie Morpheus International, Inc., 1998.

${ }^{26}$ BARLOWE, Wayne. Brushfire. Illuminations from the Inferno, Beverly Hills, Galerie Morpheus International, Inc., 2001.

${ }^{27} \mathrm{~A}$ citação é de um trecho do épico Paradise Lost.

${ }^{28}$ Tanith Lee é uma escritora inglesa, nascida em 1947 em Londres, de livros do gênero fantástico, ficção científica e horror.
}

apresentação, as seis páginas de introdução dos capítulos e as duas páginas finais, que embora bastante escuras, apresentam imagens do que parecem ser tijolos, com partes de esqueletos humanos incrustados. O efeito pretendido é cênico, busca recriar na linguagem gráfica uma progressiva entrada no ambiente do Inferno. E representa também, pelo uso da cor negra, a escuridão, o contrário da luz, o mistério, o lugar do medo que todos procuram evitar.

O partido gráfico adotado com a cor negra também serve como um fundo contrastante com as ilustrações, ressaltando o seu colorido, que se faz vibrante apenas nas cores vermelhas do sangue e nos amarelos alaranjados do fogo. Seria interessante por uma razão descritiva dizer que nas ilustrações as cores existentes são: o vermelho (fogo e sangue), o amarelo (fogo), o laranja (fogo) e o gris, em tonalidades verdes, marrons e azuis (magma resfriado dos corpos dos danados, de alguns demônios e da paisagem). A cor primária predominante nas ilustrações do Inferno é a vermelha, com algum uso de amarelo e nenhum de azul. A cor secundária laranja é usada somente no fogo. O verde inexiste. As cores restantes são do grupo dos grises (cinzas), azulados, marrons e esverdeados. Ainda, em termos da sua programação gráfica, o livro dispõe os textos nas páginas à esquerda e as ilustrações à direita, correlacionando o conteúdo literário com as suas respectivas imagens. As exceções são os sketches, desenhos de estudos das figuras do Inferno que não tem texto, aparecendo nos dois lados das páginas.

O livro está dividido da seguinte maneira: as páginas de apresentação, sendo que uma inclui uma citação de John Milton ${ }^{27}$, uma introdução de Tanith Lee ${ }^{28}$, um prefácio e quatro partes, que são divididas tematicamente em Paisagens, Demônios, Almas e Sketches, do próprio Barlowe, a página de fechamento com um autorretrato e a cronologia dos seus trabalhos. Os textos que iniciam os capítulos possuem cores diferentes, sendo de um gris marrom esbatido o das Paisagens, de vermelho vivo o dos Demônios, e de um gris azul esbranquiçado o das Almas.

O exemplar que utilizei de Brushfire: Illuminations from the Inferno é a primeira edição publicada pela Galerie Morpheus International, Inc., Beverly Hills, CA, em setembro de 2001. O livro continua a incursão imaginária de Barlowe ao reino inferior, iniciada com o seu primeiro livro Barlowe`s Inferno. A concepção gráfica, as ilustrações e o texto são de autoria de Barlowe.

Em termos do seu projeto gráfico, este livro diferencia-se do seu antecessor por apresentar-se num formato de portfólio, que muito se assemelha aos manuscritos medievais. Daí seu título incluir a palavra iluminura, 
atribuindo um sentido litúrgico e antigo ao seu conteúdo. Novamente, nesse livro, como no anterior as páginas iniciais têm fundo de cor negra, mas assim que as ilustrações aparecem, o fundo das páginas passa a ter uma textura similar à da pele humana escurecida. O significado fica evidente: pergaminhos ${ }^{29}$ eram feitos com peles de animais, maceradas em cal, raspadas e polidas para servir de material de escrita ou de encadernação. No caso desse livro, por se tratar de uma representação do Inferno, cuja natureza local é a punição da humanidade pecadora, a pele utilizada é a do animal conhecido por sua designação latina de homo sapiens.

\subsubsection{O texto}

Esse livro é apenas uma parte de um projeto maior, há muito alimentado por Barlowe, de escrever e ilustrar o Inferno, denominado de $A$ Pilgrimage to $\mathrm{Hell}^{30}$. O projeto vem ocupando parte do tempo de Barlowe, há cerca de 15 anos, ocasião em que ele fez a ilustração que o motivou para desenvolver a série. A ilustração representa um demônio menor chamado Valefar. Barlowe ${ }^{31}$ informa que se inspirou numa velha foto de uma mulher árabe inalando incenso, trajando um pesado manto, pertencente ao seu arquivo de imagens. Barlowe, então, traduziu essa imagem do manto em pele humana, com mamilos e pelos púbicos, e adornou a figura com um colar feito de intestinos, nele pendurando um coração, dois olhos e rins. 0 tratamento formal da figura possui, propositalmente, uma certa elegância, com uma faca de açougueiro sutilmente pendurada na sua luva direita. Devido ao efeito perturbador que a ilustração causou nas pessoas que a viram, Barlowe decidiu fazer uma sequência livre de outras ilustrações que se referissem ao tema do Inferno. Foi então que Ihe ocorreu a ideia de desenvolver o projeto da peregrinação ao Inferno. Barlowe se refere a esse projeto maior como sendo o seu "pet project"32, e diz que "O escopo do tema é tão fascinante e vasto, histórica e visualmente falando, que não consigo tirar da minha cabeça"33. Acrescenta ainda que "em termos de fantasia e interação humana a matéria prima do Inferno é enorme e multicultural"34. Escolhe, desde já, o nome do protagonista que fará a peregrinação no Inferno, Frank Baker.

No prefácio do Barlowe's Inferno consta uma observação importante para a compreensão do multiculturalismo ${ }^{35}$ que caracteriza a sua representação literária do Inferno. Barlowe nos diz que quando iniciou as leituras sobre o mundo inferior, "o ecletismo passou a ser um imperativo inegável; o Inferno deveria servir para todas as culturas"36 e acrescenta que "para mim a resposta estava em absorver quantas referências culturais, em termos de imagens relativas à morte e ao mundo inferior, fosse possível coletar" ${ }^{\prime 37}$. Evidentemente que Barlowe, como ilustrador, organizou as imagens segundo seus próprios critérios, transformando-as, redesenhando-as, de modo a se ajustarem ao seu senso estético e à sua visão do que seria o Inferno. Novamente, estava ele aqui a trabalhar de um modo bastante parecido com o que utilizou para desenvolver projetos anteriores de criação de mundos alienígenas, como por exemplo, o de Expedition. O terceiro parágrafo do prefácio escrito por Barlowe nos permite entender a concepção pluralista ${ }^{38}$ do seu Inferno, em termos das diversas noções religiosas que o compõem:

Os temas do bem e do mal, em minha opinião, transcendem os limites da religião. Eles são as bases da ética e daquilo que significa ser humano. Por isso decidi, logo de início, não privilegiar nenhuma religião corrente na criação do inferno. Não quis impor nenhum limite a minha criatividade e nem entrar nos assuntos da religião comparada, terreno pantanoso quando se lida com um tema tão emocionalmente carregado quanto o do inferno. Embora o inferno da literatura judaico-cristã seja seminal, não é, necessariamente, das mais ricas imagens descritivas do mundo inferior. Muitas outras culturas são de uma vívida originalidade quando se referem a esse tema. Penso também naquelas religiões que séculos atrás eram levadas a sério e que hoje não passam de tristes ecos de rituais esquecidos. Ignorá-las totalmente seria injusto, portanto as influências dos Egípcios, dos Maias e de outras civilizações são evidentes. No entanto, eu me assegurei de não incluir nenhum artefato de nenhuma época em particular. ${ }^{39}$

${ }^{29}$ Pergaminho origina-se, etimologicamente, do Grego pergamene e do Latim charta pergamena. Sua invenção é tradicionalmente atribuída a Eumenes II de Pergamum em 197158 ac. Encyclopedia Britannica, edição de 1963, volume 17, p.281.

${ }^{30}$ Uma Peregrinação ao Inferno.

${ }^{31}$ BARLOWE, Wayne. The Alien Life of Wayne Barlowe, Beverly Hills, Morpheus International, pág.8.

${ }^{32}$ Projeto de estimação.

${ }^{33}$ BARLOWE, Wayne. Op., cit, pág.8.

${ }^{34}$ Revista Starlog, fascículo 259, fevereiro de 1999, pág.46.

${ }^{35}$ Multiculturalismo aqui entendido no sentido mais positivo do termo significando coexistência enriquecedora de diversos pontos de vista, interpretações, visões, atitudes, provenientes de diferentes bagagens culturais. De acordo com o artigo do cientista e professor da USP Roberto Fernandez, "O multiculturalismo apregoa uma visão caleidoscópica da vida e da fertilidade do espírito humano, na qual cada indivíduo transcende o marco estreito da sua própria formação cultural e é capaz de ver, sentir e interpretar por meio de outras apreciações culturais. $O$ modelo humano resultante é tolerante, compreensivo, amplo, sensível e fundamentalmente rico: a capacidade interpretativa, de observação e até emotiva, se multiplica". Publicado na Revista USP (Universidade de São Paulo), no. 42, junho/agosto de 1999, págs. 84-95.

${ }^{36}$ BARLOWE, Wayne. Barlowe's Inferno, Beverly Hills, Morpheus International, 1998, pág.10.

${ }^{37}$ Idem, pág. 10.

${ }^{38}$ Pluralismo significando a coexistência de variadas representações de diferentes contextos históricos de culturas diversas.

${ }^{39}$ Tradução livre. 


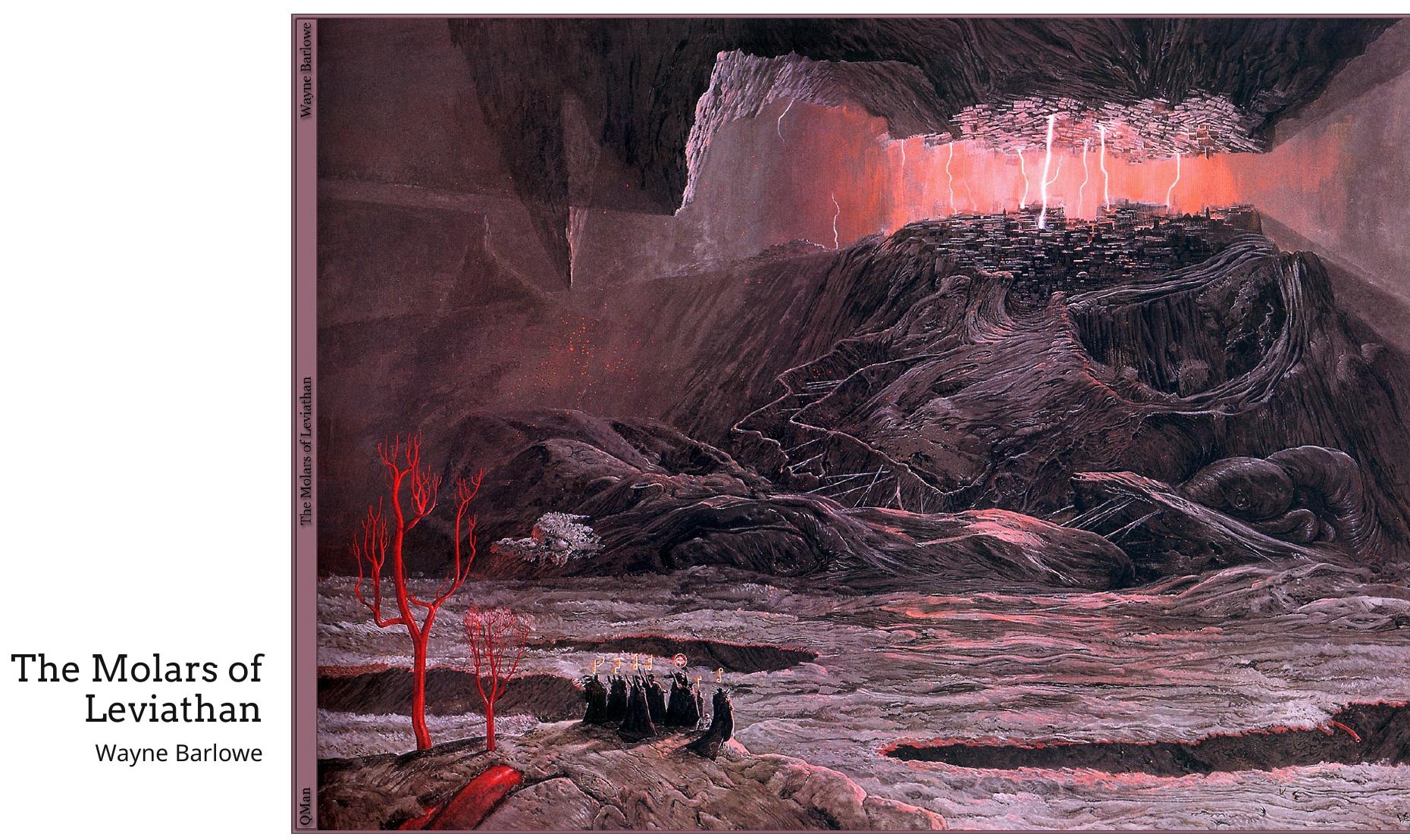

Barlowe comenta ainda a respeito da sua concepção do Inferno que a cor principal que utilizou nos ambientes ilustrados foi um marrom acinzentado.

Essa cor lhe sugeriu uma atmosfera densa, opressiva, carregada e que em alguns lugares provoca intensos e gigantescos lampejos de eletricidade estática. Sugeriu, também, uma vastidão que Barlowe acha apropriada, pois os infernos claustrofóbicos do passado não tinham, na sua opinião, a escala grandiosa que um lugar destinado a humilhar e a oprimir a humanidade deveria ter, tornando as almas danadas ridiculamente minúsculas.

Barlowe diz que o seu Inferno conjuga temporalidades diferentes e simultâneas: é muito velho e recémnascido. Existe num tempo próprio e absurdo, sendo habitado por uma população composta, simultaneamente, dos seus mais antigos antepassados

${ }^{40} \mathrm{O}$ termo que Barlowe utiliza para movimento é kinetic, aquilo que produz ou causa movimento, segundo o The Oxford Universal Dictionary, Vol.I, Londres, Oxford University Press, 1961.

${ }^{41}$ Os termos utilizados por Barlowe são sigils e glyphs. Sigil tem por sinônimo a palavra seal, que de acordo com o Oxford Universal Dictionary Illustrated, significa selo. Na astrologia é um signo oculto supostamente possuidor de poderes misteriosos. Num outro uso, relaciona-se ao termo sigla, indicando letras (especialmente as iniciais) ou outros caracteres utilizados para denotar palavras. A palavra sigla no seu uso no campo da paleografia, significa letra inicial simples ou repetida, utilizada como abreviatura em monumentos, medalhas e manuscritos. Por último, o termo glyph, ou glifo em português, é de uso raro e quer dizer como dos seus descendentes ainda não nascidos. É possível ver um degradado Homo erectus andando ao lado de um indivíduo moderno. Isto, em sua opinião, enfatiza a atemporalidade do Mal.

A descrição da paisagem do Inferno que Barlowe resume no sexto parágrafo do seu prefácio tem para mim uma importância fundamental, pois indica o foco da minha análise, relacionando as metáforas corporais à natureza substancial do mal supremo residente no Inferno. Escreve Barlowe:

A paisagem do Inferno é dotada de um movimento sem fim $^{40}$. O chão mesmo, bem debaixo dos nossos pés, é como um organismo metamórfico vivo, que nunca descansa e que é de tal magnitude, que não consegue identificar um sentido inteiro da sua verdadeira natureza. Ele pode estar quieto e silencioso num momento e agitar-se num rugido, no próximo.

Barlowe diz que o solo despedaçado é composto de restos de pessoas, arrancados das edificações das vastas obras da cidade infernal. Debaixo do chão deitase uma camada de asfalto negro e viscoso, matriz daquilo que é o supremo Mal do Inferno. Olhando-se para cima, por entre nuvens agitadas, pode-se discernir glifos e selos ${ }^{41}$, perenes e ardentes, que formam e transformam ciclicamente nomes e proclamações malditos. São os encantamentos, silenciosos, que guardam o Inferno dos seus inimigos. 
Na entrada da cidade de Dis existe um gigantesco arco arquitetônico chamado The Wargate ${ }^{43}$, e a sua imagem consta na ilustração que mostra um desfile de demônios e almas danadas. O grupo marcha na cadência das batidas de um enorme coração negro que se encontra suspenso sob o arco do Portão. Um demônio maior lidera a coluna de almas, que serpenteia para fora da cidade infernal. O Portão da Guerra foi construído em comemoração à derrota das falanges dos anjos rebeldes e é um dos maiores monumentos já erigidos no Inferno. É uma titânica estrutura orgânica que não poderia existir sem a extensa rede de artérias e órgãos que a mantêm viva. Barlowe baseou-se no Paraíso Perdido de Milton para a realização desta ilustração. Ele acredita que a obra de Milton é um dos pontos altos da literatura mundial, e a sua leitura o deixou bastante motivado para interpretála visualmente. Barlowe destaca a grandiosidade da arquitetura na concepção do Inferno miltoniano, cuja potência das imagens inspirou dois brilhantes artistas do século XIX, John Martin e Gustave Doré. Outra influência na concepção deste imenso arco

${ }^{43}$ O Portão da Guerra, a ilustração se encontra na página 27 do Barlowe's Inferno. No seu aspecto técnico, Barlowe comenta que esta ilustração em grande formato foi uma das mais complexas e que mais tempo tomou na sua execução. Foi pintada sobre papel montado em prancha da marca Schoellerhammer Parole, a tinta utilizada foi acrílica da marca Lascaux e os pincéis foram Winsor \& Newton Series $7 \mathrm{~s}$. A dimensão da ilustração publicada é de $18,2 \mathrm{~cm}$ de altura por $27,2 \mathrm{~cm}$ de largura. comemorativo da decisiva batalha que expulsou as forças de Satã para o Inferno, foi o interesse declarado de Barlowe pela Primeira Guerra Mundial. A ironia, proposital, é a de que este arco triunfal comemora na verdade uma derrota. A temática dos frisos esculpidos por sobre toda a superfície do portão é a derrota das forças de Satã. Os trágicos demônios aí representados são, na visão de Barlowe, idealizações da verdadeira natureza das hordas da escuridão. Barlowe admite ainda, uma influência temática devida ao arquiteto do Terceiro Reich alemão, Albert Speer, quanto à pompa e grandiosidade da arquitetura do seu Inferno.

Com respeito às almas danadas eternamente encarceradas no Inferno, Barlowe as concebeu como sendo um recurso natural que os demônios se aproveitam para tirar todos os tipos de vantagens. Elas se apresentam numa variedade infinita de formas e não são poucas as destinadas a serem os tijolos que erigem alguns dos edifícios.

As almas danadas perambulam pelas ruas simplesmente para que os demônios se sintam mandatários de um reino habitado. Elas são meros figurantes atuando inconscientemente no palco do Inferno. Suas formas são infinitamente variadas, não existindo duas iguais, esculpidas pelas mãos depravadas e perversas dos seus maléficos senhores. Uma imagem representativa desta relação entre demônios e danados é a que Barlowe chamou de The

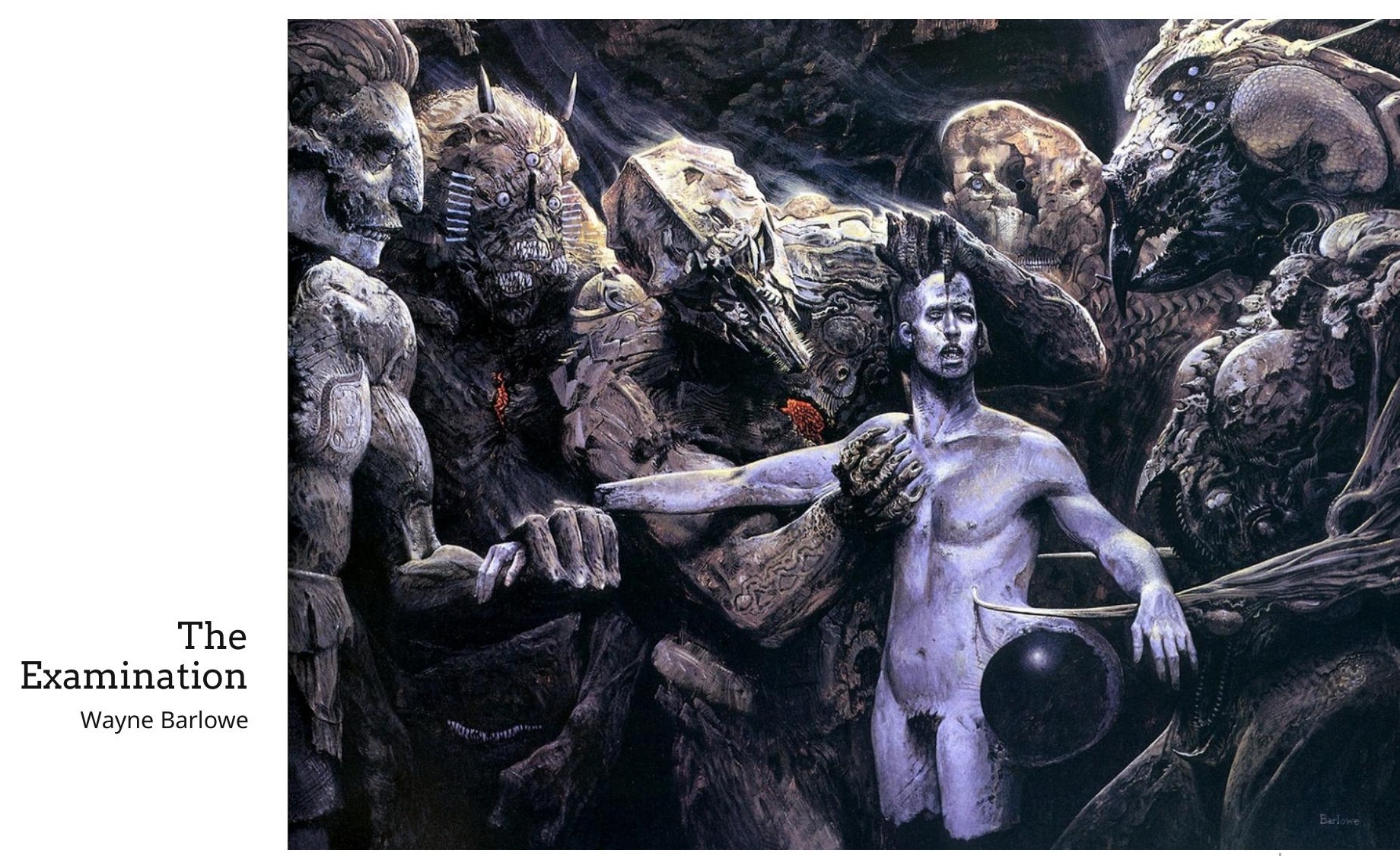




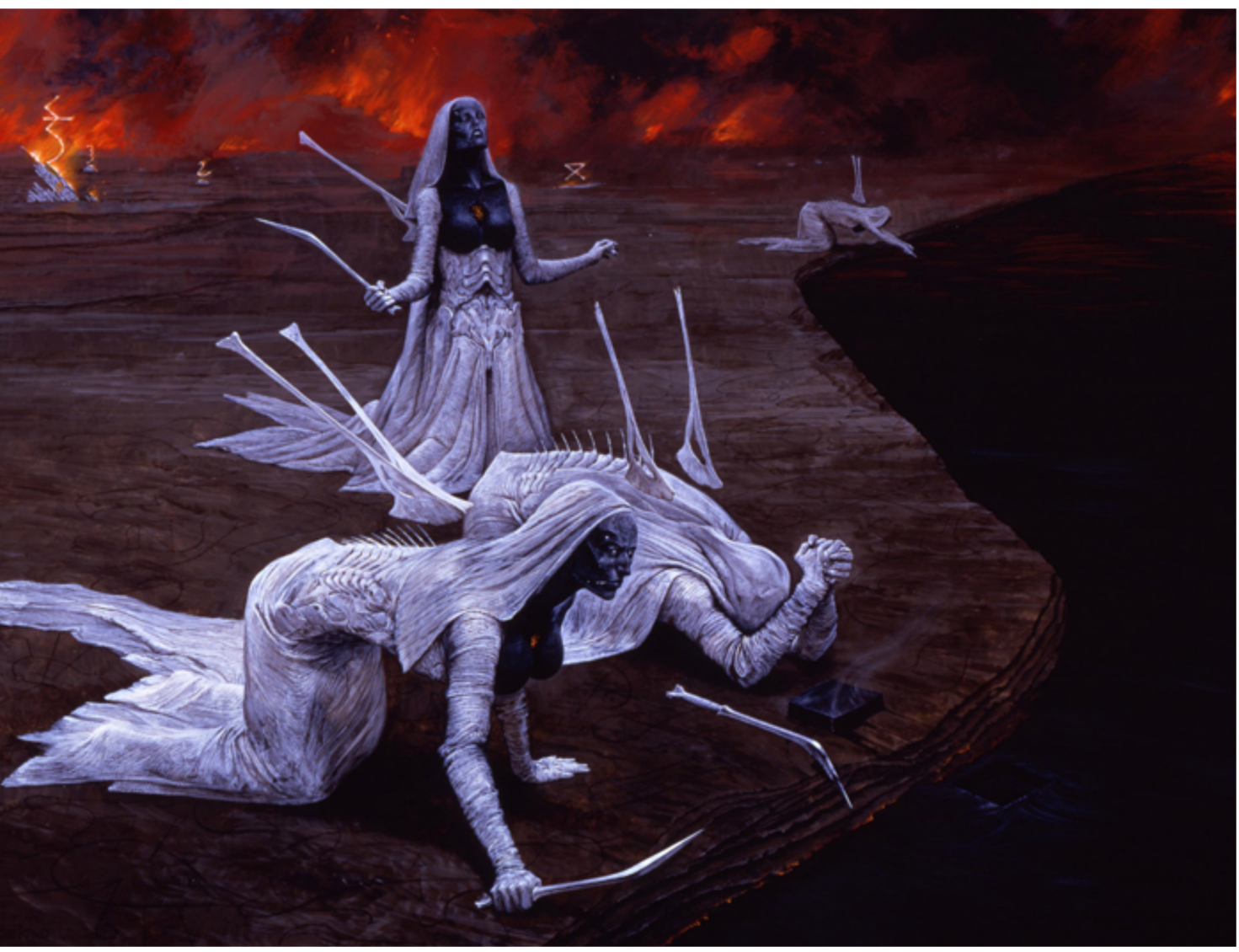

\section{Unholy Communion}

Wayne Barlowe
Examination $^{44}$. A ilustração mostra um grupo de demônios a examinar curiosa e detidamente um danado. Na verdade, conforme explica Barlowe, eles estão a praticar uma vivissecção. O termo designa um tipo de operação feita em animais vivos para estudo de fenômenos fisiológicos, e a sua utilização numa intervenção que envolve uma alma, afinal de contas humana, demonstra o desprezo a que estão relegados os danados no Inferno de Barlowe, reduzidos à condição de animais. Demonstra também, um aspecto lúdico semelhante ao do Inferno medieval, em que o jogo e o entretenimento satisfazem a uma curiosidade que remonta aos tempos da infância.

$\mathrm{Na}$ caracterização dos demônios do seu Inferno, Barlowe estabelece uma ordem hierárquica que os distribui segundo verdadeiras castas infernais. Seres de aparência polimorfa, amargurados pela situação, são, no íntimo e paradoxalmente, orgulhosos das suas realizações. Tudo o que existe no Inferno, sejam os monumentos, os ornamentos e os danados, é para agradá-los. Em termos da sua aparência física os demônios variam muito. As mais primitivas criaturas do Inferno são demônios predadores, criaturas enormes, nativas da região, que aguardam famintas para devorar quem porventura cruzar os Portões. Os demônios menores são criaturas simples, sem adornos, cujas tarefas consistem em serem guardas e pastores, enquanto os demônios maiores não somente comandam suas próprias guardas em Dis como são investidos de notáveis poderes. Um desses poderes é a capacidade de constantemente se metamorfosear, qualidade simbólica da sua condição de nunca ter descanso. Barlowe diz que os seus demônios prediletos são os de natureza miltoniana, derrotados numa guerra que teve lugar há muito tempo atrás, mas que permanecem orgulhosos e altivos, mesmo que caídos.

Consta uma evidência muito significativa da existência do corpo gigantesco de Lúcifer no Inferno de Barlowe. Trata-se da ilustração Unholy Communion ${ }^{45}$ que mostra as Freiras do Inferno, ou as Filhas de Lúcifer, como são mais conhecidas, a prestar culto ao seu mestre. Elas são demônios menores, membros de um misterioso e importante culto, e se encontram em todos os lugares do Inferno, notadamente visíveis em seus hábitos brancos, espalhando a palavra de Lúcifer. A sua iniciação é terrível e envolve inverter a própria pele dentro do poço ardente. Para tanto Ihes é fornecida a única possessão cabível, uma lâmina branca e angulada, com a qual executam a tenebrosa tarefa em meio ao fogo carbonífero. Quando elas emergem, sua nova pele escorchada é de um negro profundo. As

${ }^{44}$ O Exame, a ilustração consta na página 55 do Barlowe's Inferno. ${ }^{45}$ Comunhão profana, a ilustração é a nona do Brushfire: Illuminations from Hell (as páginas não são numeradas no pórtfolio). 
sacerdotisas, muito antigas, são as que presidem o culto, ficando confinadas numa caverna sagrada na montanha nomeada de Orelha de Lúcifer. Nunca são vistas, mas fazem seus editos por meio de intermináveis correntes de escritas criptografadas que somente um grupo seleto pode interpretar. Alguns dizem que essa linguagem parece com a antiga escrita dos anjos. O objetivo principal das Filhas é a peregrinação pelo Inferno para comungar com Lúcifer. Elas atravessam as vastidões ardentes, tendo por fim atingir a região extrema do substrato negro, que se encontra nas profundezas da região infernal. Este lugar sagrado é conhecido por Mortalha de Lúcifer, onde elas completam a peregrinação, para então comer do verdadeiro Rei do Inferno. As sacerdotisas ensinam que o substrato é o que restou de Lúcifer após a queda. Depois de atingirem este ponto, as Filhas devem solenemente extrair um pedaço da substância negra e engoli-la por inteiro, para serem unas com Ele.

Essa substância é a fundação sobre a qual o Inferno se assenta. A inspiração para isso, segundo Barlowe, veio de uma antiga e obscura referência a uma agitada escuridão num poço. O interessante aqui é que ao evitar a nomeação do que ele chama de o rei supremo do Inferno (geralmente chamado de Demônio, Diabo ou Satã), Barlowe realiza uma notável transferência simbólica da sua figura mítica, atribuindo-a aos elementos da natureza do Inferno (a substância betuminosa escura e dotada de consciência, a cidade de Dis com seus telhados cabeludos e a paisagem de uma forma geral), que passam a "encarnar" a personalidade do Demônio. Embora isso não venha a constituir uma novidade literária (metáforas corporais se fazem presentes em livros sagrados de diversas religiões há muito tempo ${ }^{46}$ ), cria-se uma significativa e diferenciada representação do Mal no Inferno personificando a sua Natureza.

O conjunto das menções ao corpo metafórico, que no seu Inferno se faz fragmentado, dividido, grotesco, repulsivo e gigantesco, compartilha o mesmo regime representativo de um outro fenômeno, a metamorfose. Esse, também, não é novidade nenhuma. Mas a fusão desses fenômenos de transferência de significado e transformação do corpo, metáfora corporal e metamorfose, respectivamente, faz do Inferno de Barlowe um todo fragmentado, metamórfico, em

\footnotetext{
${ }^{46}$ A Bíblia, por exemplo.

${ }^{47}$ Cito aqui como exemplo de um Inferno da ficção literária moderna o constante na fantasia criada por J. R. R. Tolkien (1892-1973) intitulada de Senhor dos Anéis (recentemente adaptado para o cinema). A história é implicitamente cristã embora ambientada num outro mundo (a Terra Média). O senhor do mal Sauron, que reina absoluto na terra maldita de Mordor (o Inferno), está associado ao Demônio pela serpente ou dragão (do grego sauros).
}

contínuo processo de destruição e reconstrução, uma representação figurada de um mito. Barlowe assume de pronto a sua obra como sendo um trabalho de ficção, uma criação imaginada, e adverte, já na apresentação, que as ilustrações do seu livro não são baseadas em nenhuma viagem real ao Inferno. Elas são um trabalho da sua imaginação e não foram produzidas sobre nenhum tipo de influências alucinatórias, psicóticas ou qualquer que seja. Diz ainda que nunca foi ao Inferno e não tem planos imediatos para empreender essa jornada particular.

O tom irônico e defensivo dessa última frase aponta para a diluição gradativa da noção religiosa na concepção de imagens do Inferno, que na contemporaneidade se torna mais e mais individualizado. Indica também, uma adição nos parâmetros dos infernos literários mais representativos da modernidade ${ }^{47}$ : o Inferno em Barlowe se faz exclusivamente no reino da imaginação, conformando uma aventura num clima de expedição científica e exploratória a um novo mundo, uma jornada fantástica, em que o entretenimento se faz elemento central da sua representação. Pode-se dizer que se trata da representação de um Inferno feito sob medida para a diversão dos leitores, para agradar ao público adolescente americano ávido por histórias de horror. Pode-se dizer até, que é um Inferno desprovido de um genuíno sentimento religioso, devido ao ecletismo e atemporalidade, que não manifesta, já na sua concepção, uma fé legitimadora, garantia da sua identidade histórica. Ao recusar uma orientação religiosa mais específica, ou um sistema doutrinário de base, particularizado e orientador do seu universo de imagens, Barlowe parece correr o risco de anular por total a identidade religiosa da sua representação do Inferno. De fato, ele declara:

\begin{abstract}
Se eu acredito no Inferno? Não no sentido tradicional, mas posso arriscar dizer que, num sentido maniqueísta alterado, todos estamos vivendo o nosso próprio Inferno. Como é possível o mundo nos dar Da Vinci, Shakespeare e Mozart e nos dar também Hitler, Pol Pot e Stalin?
\end{abstract}

Barlowe faz uma nítida distinção entre o Inferno imaginário representado na literatura e na arte daquele existente no mundo real, quando sustenta que os infernos que a humanidade cria na arte e na ficção não podem competir com os infernos reais que ela própria se inflige num mundo do crescimento da violência e do esquecimento da ética.

Note-se que Barlowe trata da dicotomia do bem e do mal como atributos exclusivos da raça humana, responsabilizando-a por uma possível extinção planetária advinda das ameaças atuais do terrorismo nuclear e biológico. 
A separação que Barlowe faz entre o Inferno representado na arte, fictício, ilusório, aparentemente destinado à diversão e ao entretenimento popular, e o Inferno da vida real, vivenciado concretamente, leva à problemática da relação entre imaginação e arte, e da função simbólica que a permeia. Dá a pensar nas razões que realmente o motivaram a representar o Inferno numa contemporaneidade em que a dor e a violência se fazem costumeira e assustadoramente presentes no cotidiano das sociedades, como ele mesmo indaga no seu prefácio:

Será que alguém se pergunta por que é que a metade das notícias diárias é feita de tragédias e crimes? Porque aceitamos o sensacionalismo dos mais horríveis crimes, será por mera diversão dos indivíduos entediados com o cotidiano das suas vidas? Qual é a feiura que se encontra logo abaixo das peles da maioria dos nossos indivíduos e que nos leva a praticar atos tão egoístas? Por que fazemos coisas tão feias e questionáveis e por que nos interessamos tanto quando outros fazem o mesmo?

\section{Influências e rupturas}

A passagem do Inferno do campo da criação artística e literária para o campo do entretenimento comercial constitui uma ruptura. A produção de esculturas de demônios do Inferno de Barlowe em escala comercial evidencia uma banalização da "terribilita" do Inferno. O Inferno de Barlowe diferencia-se pela inexistência de uma regra teológica cristã que, de acordo com o de Doré, por exemplo, racionaliza a divisão do ambiente infernal e dá um sentido claro e didático às penas dos condenados. O Inferno de Barlowe conforma um sistema de representação individualizado e sem o caráter da dualidade divina da tradição judaicocristã, onde a onipresença maligna de Satã se opunha à figura benigna de Deus. De fato, não existe uma figura maléfica principal que dê sentido ao próprio Inferno, como lugar de punição, e que se estabeleça como autoridade central que a todos governa, como o Demônio cristão.

Vale aqui lembrar que, de acordo com a tradição cristã, existe uma íntima relação entre a conformação espacial do Inferno e o corpo de Satã. Este, como resultado da sua insubordinação a Deus, é expulso do céu e, numa das versões da estória da guerra no céu, a queda do seu corpo na terra provoca a abertura de um imenso buraco no formato de um cone invertido. Esta seria a principal inspiração para o Inferno de Dante, no tocante a sua geografia, com os nove círculos decrescentes indo terminar no poço onde se encontra o próprio Demônio. Com Dante, a arquitetura do Inferno se torna mais concreta, se define enquanto espaço dos suplícios, e conforma uma intima relação com o corpo do Demônio. Seus espaços são cheios de corpos. Esse novo espaço infernal pode ser resultado da crescente exigência do clero, a partir do século XIV, na definição dos castigos que são impingidos aos danados. É esta qualidade de ser concreto, material, pétreo, que Barlowe vai traduzir para a atualidade.

No Inferno de Barlowe a divisão dos espaços é feita segundo disputas territoriais entre os diversos demônios que o habitam. A hierarquia entre os demônios estabelecese mediante o uso da força. A lógica que impera é a da seleção natural onde o mais forte e capaz sobrevive e, portanto, domina. A ideia que aqui se desenha reporta-se a um contexto cultural onde a herança da obra de Charles Darwin, principalmente a Origem das Espécies, deu base ao desenvolvimento das modernas teorias da evolução natural. Pode-se falar aqui, inclusive, sobre a influência que os pais de Barlowe, sendo ilustradores científicos do Museu de História Natural de Nova York, certamente exerceram na sua formação. Prova disto é que Barlowe frequentou em 1976, como aprendiz, o Departamento de Exposições do referido museu. Mas o ponto crucial é que no Inferno de Barlowe quem governa é a "Natureza" e não mais o Demônio. Esta "Natureza”, vista pela definição moderna de uma força ativa que estabeleceu e conserva a ordem natural de tudo quanto existe, nos remete às teorias atuais da origem do universo, uma delas sendo relativa a uma grande explosão inicial, também conhecida por Big Bang. Historicamente, tais fatos indicam a mudança que ocorreu no quadro conceitual da figuração do Inferno, do séc. XIX para o séc. XX. No primeiro, a referência é ainda predominantemente religiosa, como no caso das ilustrações do Inferno de Dante por Doré48, mas, no segundo, o determinismo biológico da visão científica substituiu, gradativamente, a instância da religião, como fica claro nos escritos e nas figuras infernais de Barlowe. $\mathrm{O}$ pensamento científico é que vai servir como indutor das novas figurações do Além, estabelecendo novos parâmetros da imaginação, onde o espaço sideral compõe uma das principais referências. E também onde os habitantes de outros planetas - os extraterrestres compõem o imaginário contemporâneo do gênero fantástico. No caso do Inferno de Barlowe, os extraterrestres integram os demônios. Os livros anteriores ${ }^{49}$ concebidos por Barlowe relacionam-se a essas questões.

O aspecto da arquitetura monumental e teatral do Inferno de Barlowe desenvolve-se a partir da influência, por ele mesmo citada, do artista inglês John Martin (1789 - 1854), pintor e gravador inglês do séc. XIX. Era também conhecido por "Mad Martin" e foi um dos mais

${ }^{48}$ DORÉ, Gustave. The Doré Illustrations for Dante's Divine Comedy, New York, Dover, 1976.

${ }^{49}$ Guia de Extraterrestres de Barlowe - 1979 - Workman Publishing. Expedição - 1990 - Workman Publlishing The Alien Life of Wayne Barlowe - 1995 - Morpheus International. 


\section{The Fallen Angels Entering Pandemonium}

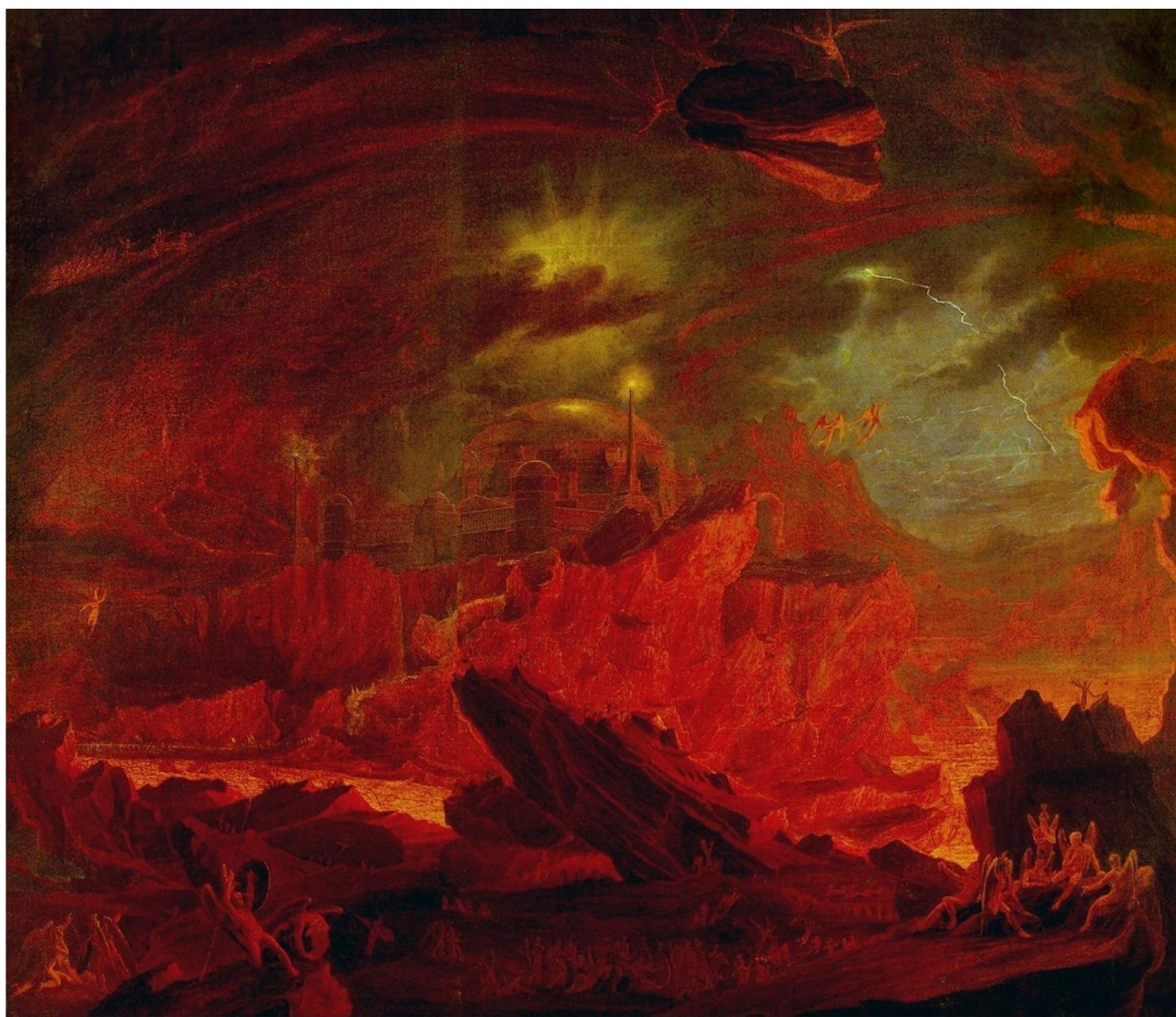

significativos pintores dos temas românticos da pintura inglesa do período. Muitas das suas telas eram de grande escala o que enfatizou o seu impacto visual e o tornou conhecido do público apreciador da arte da época. Martin era um especialista de temas apocalípticos, de épicos e da representação da arquitetura numa dimensão heroica. Existe uma pintura de sua autoria na Tate Gallery de Londres que marca a principal influência visual no Inferno de Barlowe. A obra, pintada em 1840, é intitulada The Fallen Angels Entering Pandemonium ${ }^{50}$, e mostra os elementos que mais caracterizam a concepção visual do Inferno de Barlowe: a vastidão das planícies infernais, o rio de fogo feito de lava vulcânica (que no uso das cores justifica os intensos vermelhos, laranjas e amarelos), a escuridão cavernosa, os raios cortando a atmosfera sulfurosa, os diminutos grupos de demônios que integram a paisagem do

\footnotetext{
${ }^{50}$ A Entrada dos Anjos Caídos no Pandemônio.

${ }^{51}$ Honoré Daumier (1808 - 1879), pintor, gravador e caricaturista francês, deixou uma vasta produção de litografias e trabalhos gravados em madeira (mais de 4000). Artista bastante popular, era em termos de estilo, um romântico idealista, cuja obra incluiu no seu repertório assuntos tanto populares (saltimbancos), como grandes temas poéticos (ilustrou Dom Quixote).
}

Inferno, acentuando a sua enormidade, e a monumentalidade e ecletismo do palácio infernal, que mistura elementos arquitetônicos muçulmanos, cristãos e egípcios. Martin também ilustrou, em 1824, o Paraíso Perdido de Milton numa série de gravuras em que demonstrou o correto entendimento da vastidão subterrânea iluminada por fogos fátuos, sugerida literariamente pelo poeta inglês. Outra influência marcante de Barlowe foi a de Gustave Doré.

A versão do Inferno de Dante elaborada por Gustave Doré estabeleceu um parâmetro importante de representação ilustrada que, refletindo um imaginário do além, característico do séc. XIX, teve enorme sucesso de público, quando da sua primeira publicação em 1861 em Paris. Gustave Doré foi um dos mais bem sucedidos ilustradores do século XIX. Nasceu em Estraburgo na França em 6 de janeiro de 1832 e faleceu em Paris em 23 de janeiro de 1883. Iniciou a carreira cedo, aos 15 anos, após uma viagem a Paris, quando então passou a elaborar regularmente litografias para o mercado editorial parisiense. Estes primeiros trabalhos eram caricaturas executadas na maneira de Honoré Daumier ${ }^{51}$. Em 1854 ele produziu belas e bizarras ilustrações para 
uma edição de Rabelais, e daí em diante ilustrou, segundo um plano sistemático, alguns dos grandes clássicos da literatura mundial. Incluídos, entre outros, estão, Contos Divertidos (1856) de Balzac, Contos de Fadas (1861) de Perrault, Dom Quixote (1863) de Cervantes, a Bíblia (1865 - 1866) e Paraíso Perdido (1866) de Milton. Estes tiveram um grande número de edições e foram distribuídos em muitos países. Um trabalho como a Bíblia de Doré era uma posse estimada por inúmeras famílias da classe média francesa.
A iniciativa de ilustrar a Divina Comédia de Dante Alighieri foi em 1855. A primeira tiragem, bancada pelo próprio Doré, foi editada em 1861. Apesar de não ler italiano e provavelmente ter utilizado a tradução francesa em prosa de Pier Angelo Fiorentino, seu estudo da obra prima do mestre florentino foi completo. E intenso, como bem o demonstram as ilustrações feitas, encontrando um significativo paralelo em Michelangelo Buonarotti. O mestre de Caprese teve por influência literária maior, depois da Bíblia, Dante

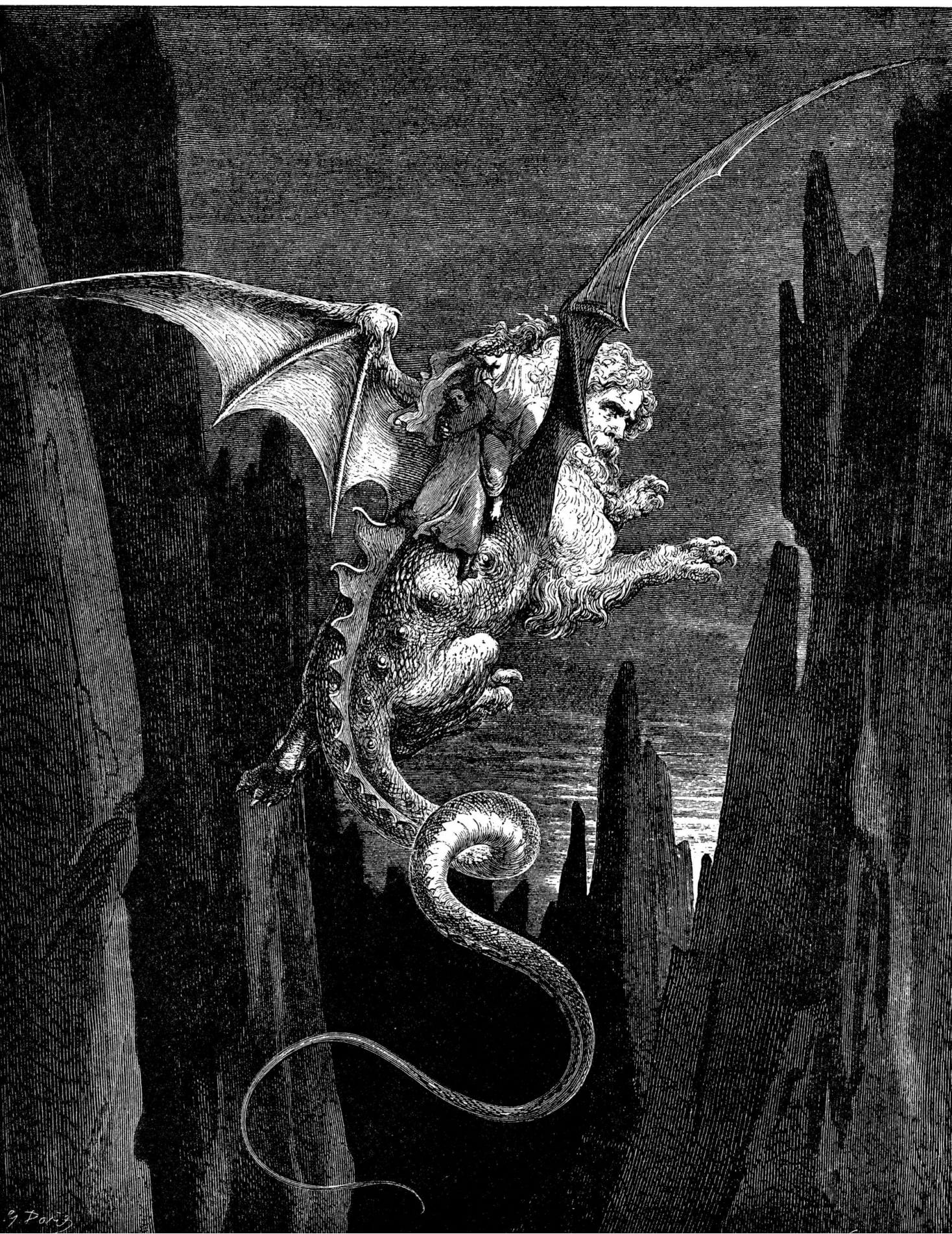

The Descent into the Abyss on Geryon's Back

Gustave Doré 
Alighieri. Michelangelo lia Dante avidamente, e algumas vezes o imitava nos seus próprios escritos ${ }^{52}$. Foi um admirador tão intenso do poeta medieval que quis erigir um monumento em sua memória em Florença. Não é à toa que a influência maior nas figuras do Inferno de Doré, tanto dos danados quanto dos demônios é do ideário michelangelesco. Esta concepção inclui o desenho de corpos idealizados, em termos de aparências e proporções, segundo os critérios da escola florentina renascentista. Inclui-se aqui, uma noção de beleza "clássica", por assim dizer, anacrônica a uma sociedade que já estava em plena revolução industrial, mas que satisfazia o gosto da emergente classe média francesa do séc. XIX.

A imagem do Inferno feita por Doré afasta-se da aparência grotesca e satírica de trabalhos anteriores e move-se na direção de um aspecto grandioso, estranho e notadamente teatral. Um Inferno de paisagens crepusculares, montanhas monumentais, abismos imensos e rios agitados, que adequou a visão de Dante ao sentido do terrível do séc. XIX. Vale ressaltar, em termos técnicos da gravura em blocos de madeira, a utilização do acentuado contraste entre negros intensos e profundos e brancos claríssimos, acentuando-se uma aparência teatral e dramatizada nas composições realizadas.

A grande admiração que Barlowe nutre pelo poema Paraíso Perdido do inglês John Milton representa, segundo ele mesmo declara, a influência decisiva na concepção do seu Inferno. John Milton foi um poeta inglês nascido em 1608 e falecido em 1674. Gerado numa família de situação financeira estável e segura e com inclinações artísticas (o pai de Milton, protestante, escrevente de profissão, era também músico e poeta), estudou desde muito cedo, encontrando um estímulo intelectual constante no culto ambiente familiar. A primeira etapa dos seus estudos foi na prestigiada escola Saint Paul, formando-se a seguir, como bacharel e "Master of Arts", na mais famosa ainda University of Cambridge. Nesse período, em que se orientava para o sacerdócio, começou a escrever poesia em latim, italiano e inglês. Logo após formar-se, passou seis anos a ler e aprofundar seus estudos na residência paterna sem a obrigação de trabalhar para seu sustento. Foi quando ele escreveu os poemas L'Allegro, Il Penseroso (1632), Comus (1634) e Lycidas (1637), todos autênticos primores no seu gênero.

Depois disso empreendeu uma viagem à França e à Itália, sendo que nessa última teve calorosa recepção e a oportunidade de ler Dante e Petrarca. Mas logo teve de retornar a Inglaterra devido à ameaça de uma guerra civil, na disputa entre a tirania de Charles I e os

${ }^{52}$ SALA, Charles. Michelangelo, Paris, Terrail, 1996, p. 135. rebeldes do parlamento, entre eles Oliver Cromwell. Milton tomou o partido dos revoltosos desde então, colocando sua pena a serviço da revolução. Com a ascensão de Cromwell foi nomeado Secretário de Línguas Estrangeiras, cabendo-lhe preparar e traduzir despachos recebidos e enviados a governos estrangeiros. Após sua decepção com o novo regime e a morte de Cromwell, Milton foi preso pelo novo rei Charles II, quando da restauração da monarquia.

Foi então que Milton trabalhou no poema épico Paraíso Perdido, que iria gravar o seu nome no rol dos mais famosos e importantes poetas da língua inglesa. Sua ambição era compor um poema épico que rivalizasse com os trabalhos de escritores antigos, como Homero e Virgílio. O poema foi originalmente editado em dez livros em 1667. Paraíso Perdido é um poema de sintaxe ímpar, de difícil vocabulário e detentor de um estilo nobre e complexo. Sua inspiração inicial deu-se, segundo Xavier da Cunha num "improvisado palco de um teatro de feira", quando da peregrinação artística de Milton pela Itália. Tratava-se de uma companhia de comediantes liderada por Battista Andreini, e a encenação em questão, de autoria do próprio, era intitulada de "Adamo". A peça, um drama sacro, narrava o empreendimento luciferino na tentação e queda de Adão e Eva, e o elenco apresentava, além das personagens bíblicas, figuras que personificavam a Carne, o Mundo, o Desespero, a Morte, a Fome, a Vanglória, o Trabalho, a Serpente, o Mensageiro do Inferno e os sete pecados mortais.

O poema narra a estória bíblica de Adão e Eva, com Deus expulsando Lúcifer do Paraíso para corromper a humanidade. Satã, que antes de rebelar-se contra Deus era chamado de Lúcifer, o mais belo dos anjos, está no seu momento mais impressionante: ele acorda num mar em chamas no Inferno cercado dos seus surpresos seguidores. Ele havia sido derrotado na guerra do Céu. Milton criou um complexo retrato de Satã, onde este figura inicialmente, grandioso, o anjo caído, sim, mas orgulhoso, poderoso, senhor das vastidões infernais, aquele que se lança, de forma impetuosa, ao desconhecido, na busca do caminho para a Terra. Mas seu intuito não é nada nobre, muito ao contrário, Satã, enlouquecido de ciúmes pela criação divina, tenciona a perdição do homem. Em função do seu extremado orgulho experimenta uma progressiva degradação e aviltamento, de supremo líder infernal vai se transformando, em general, político, espião, abutre, sapo, até se tornar uma serpente rastejante.

Estou a enfatizar Satã por dois motivos: o primeiro é que ele é a iconografia central na análise da tese, e em segundo, ele é a personagem mais notável no poema de Milton. 
Uma cena que aqui interessa, especialmente, refere-se às dúvidas que assaltam Satã, quando à vista do Éden, e perto do lugar onde devia lançar sua empresa contra Deus e o homem. Diz o poema53:

O inferno traz em si, de si em torno;

Não pode um passo dar fora do Inferno,

Porque, onde quer que vá, leva-o consigo!

É de se ressaltar o processo de interiorização psicológica do Inferno na perturbada alma de Satã. Mais na frente do poema, o drama existencial se acentua no seu espírito ${ }^{54}$.

\section{Ai de mim! Que afinal ceder me cumpre! \\ E como hei de mostrar que me arrependo? \\ Por que modo o perdão obter eu posso \\ Só pela submissão... Palavra horrível! \\ Meu nobre orgulho atira-te bem longe (...)}

A dúvida, a raiva, o medo, a inveja, o desespero, e até a solidariedade para com as legiões de seus comandados que estão a Ihe esperar no Inferno, são notadamente sentimentos humanos que Satã demonstra possuir, e que motivam todo tipo de literatura. Levaram, inclusive, o poeta místico inglês William Blake a observar que "Milton era do lado do Diabo sem o saber ${ }^{55 " . ~ T a l v e z ~ e l e ~}$ estivesse mais perto da verdade se houvesse dito que "Milton era do lado do homem ${ }^{56 " . ~}$

Outro aspecto, importante, este relativo ao livre arbítrio, surge claro numa das estrofes do cantoVI:
Livremente escolhi contra meu senso
O que tão justamente agora eu sofro!
Quanto sou infeliz! Por onde posso
Fugir de sua cólera infinita
E de meu infinito desespero?...
Só o Inferno essa fuga me depara:
Eu sou Inferno pior!

A questão do livre arbítrio possibilita o Inferno do ego, - sátiro que se inferniza. Milton preconiza a relativização do Inferno e do Paraíso na realidade do homem, no seu espírito faz alternarem-se dois estados contraditórios, o bem e o mal. Lúcifer e Satã, duas faces da mesma moeda, compõe respectivamente, a figuração do anjo eleito e do anjo caído. Não seriam todas essas condições e a sua alternância, fenômenos essencialmente humanos?

\section{No Paraíso Perdido Milton escreveu:}

O espírito é o seu próprio lugar e nele podem fazer-se Dos infernos os céus, e dos céus um inferno.

Seu poema influenciou profundamente poetas românticos como William Blake e Percy Bysshe Shelley, que viram Satã como o verdadeiro herói do poema e um rebelde contra a tirania do Céu. Claro, não poderia ser de outra forma, pois "com Milton, o Maligno assume definitivamente um aspecto de beleza decaída, de esplendor ofuscado pelo tédio e pela morte; ele é 'majestoso embora em decadência" ${ }^{57}$. Desde então, a beleza maldita passa a vigorar como a característica principal de Satã, tornando longínquo o tempo do bestial demônio medieval. Não é para menos que Baudelaire anotou em seus Journaux intimes que "o tipo mais perfeito de beleza viril é o de Satã - à maneira de Milton" ${ }^{25}$.

À animação latente da natureza e das coisas no Inferno concebido por Barlowe opõe-se a vastidão vazia e solitária que define a concepção do Inferno de Milton. A geografia do Inferno de Milton é logicamente impossível de ser determinada. Ele situa seu Inferno num oposto e o Paraíso no outro, entremeados da imensidão do caos. Na geografia de Milton predomina a vastidão vazia. É um inferno vago, que acentua o abandono de Satã.

Ao clima barroco do Inferno de Barlowe, no sentido de um extravasamento ornamental da carne, contrasta-se um classicismo redutor na depuração das formas no de Milton. O horror vacui é uma singularidade do Inferno de Barlowe. Já no de Milton, o vácuo é a própria razão de ser do ambiente infernal. O Inferno de Barlowe é eminentemente corporal, o de Milton é mental. No inferno de Barlowe predomina a fúria e a obsessão da presença do corpo, do excesso estertorante da carne; no de Milton, a solidão, o tédio e a agonia do vazio.

Contrapondo a grande fábula inumana do imaginário moderno, a da representação simbólica de seres automatizados destituídos de alma, Barlowe anima toda a natureza da sua representação do Inferno, fazendo do antropomorfismo a sua principal característica. Tal atitude aponta para uma mudança de paradigmas do imaginário de uma época em que a modernidade, já com uma considerável tradição de imagens, conjuga uma vertente de "integração ecológica" das representações humanas. Antes de significar um retrocesso histórico, essa integração do corpo com a natureza pode indicar o surgimento de uma renovada consciência, voltada para a reconstrução simbólica do desencantado homem atual. Não de um sistema de representações relacionado a um antropocentrismo histórico e idealizado, mas de uma sensibilidade que leva em conta as contradições e o aspecto fragmentário das suas simbolizações da figura

${ }^{53}$ MILTON, John. Paraíso Perdido, São Paulo, Martin Claret, 2002, Canto IV, pp.142.

${ }^{54}$ MILTON, John. Op. Cit. Canto IV, pp.145.

${ }^{55}$ Idem, p. 481.

${ }^{56}$ Ibidem, p. 481

${ }^{57}$ PRAZ, Mario. A Carne, a Morte e o Diabo na Literatura Romântica, UNICAMP, S.P., 1996, p. 73.

${ }^{58} \mathrm{BRUNEL}$, Pierre-Organização. Dicionário de Mitos Literários, Rio de Janeiro, Jose Olympio Editora, 1998, p. 817. 
humana. Que admite um compartilhamento, uma "divisão de poderes" no regime simbólico entre o homem e o restante do universo material. O homem, destituído do seu papel central na representação do mundo já desde a era iluminista, passa, no modernismo tardio, a ser definido como uma espécie de ator coadjuvante no imenso drama da vida no planeta Terra. Se no caso específico de Barlowe, o sentido da representação é o mal, o homem, enquanto alma danada encarna a natureza, comunga com ela a mesma matéria corrompida do corpo do Demônio. Torna-se um só com Ele, numa identificação especular simetricamente oposta a do homem com Deus, segundo a acepção cristã da comunhão divina.

$\mathrm{Na}$ concepção de Barlowe as almas danadas, na sua viagem para o Inferno, sofrem um intenso processo de deformação devido aos rigores da jornada. Ao chegarem ao antro infernal, passam por um novo processo de transformação, desta feita realizado pelos demônios. Como um castigo inicial, eles as esculpem, e a estética que nelas realizam deixa-as, na maioria das vezes, num estado irreconhecível. Os "refinamentos" corporais que os demônios elaboram são abstratos, caprichosos e inexplicáveis. Algumas almas podem ficar com uma aparência relativamente intocada com somente a perda de um membro, enquanto outras são transformadas em paródias barrocas da humanidade, dobradas, achatadas ou torcidas.

A forma geral dos corpos dos danados que fica sujeita a essa lógica terrível da mutilação, condicionada aos caprichos estéticos dos demônios, denota um novo arranjo de atributos a esses seres infernais, cabendoIhes o exercício de uma atividade criativa que exige sensibilidade e acurado discernimento estético. Ao imaginar essa categoria de demônios artistas, por assim dizer, Barlowe torna ainda mais complexa a relação entre os demônios algozes e torturadores e as almas vítimas e torturadas, pois a função dos demônios

\footnotetext{
${ }^{59}$ Devemos recordar que no Inferno de Dante, embora a questão da metamorfose seja importante, com exemplos significativos das almas dos suicidas transformadas em árvores no círculo e daquelas dos ladrões, tornadas serpentes no círculo oitavo, a ideia da transformação é particularizada e diferenciada (os castigos são aplicados em função dos pecados cometidos), não conformando uma regra geral punitiva, como no caso do Inferno de Barlowe. Além disso, as almas condenadas no Inferno de Dante são por ele reconhecidas, chamadas a falar, ou seja, possuem identidade, recordam e guardam semelhança com quem foram na existência terrena, cumprem sua função, de carregar a história, na estrutura conceitual do épico. ${ }^{60}$ BYNUM, Caroline Walker. Metamorphosis and Identity, New York, Zone Books, 2001, pp.184-185.

${ }^{61}$ BARLOWE, Wayne. The Alien Life of Wayne Barlowe, Beverly Hills, Mopheus International, 1995, p. 65.

${ }^{62}$ Idem. p. 65. Como se trata de uma página parcial do seu livro de anotações do Inferno, o restante do processo talvez esteja indicado nas páginas que faltam.
}

no Inferno era, tradicionalmente e segundo a didática das imagens da igreja, punir de maneira violenta os danados, tomando-se como exemplo a Idade Média.

A modificação final é uma humilhante retirada de uma parte do corpo, na maior parte dos casos a genitália, na entrada dos portões da cidade de Dis. A menção feita à retirada dos órgãos sexuais dos danados remete à questão da castratio enquanto prática histórica ritualizada. Mas essa representação tem outras interpretações - pode estar associada a um puritanismo da parte de Barlowe, pois seus demônios não possuem nenhum traço de sensualidade, aliás, nem os danados. Pode ainda dever-se ao fato de que, sendo um trabalho de ilustração, não seria apropriada a exposição de imagens francamente sexuais a um público infanto-juvenil.

Ora, claro está que na concepção de Barlowe os demônios impingem aos danados, logo que estes chegam ao Inferno, um castigo corporal de uma nova ordem, ontológica, e de uma brutalidade extraordinária: eles simplesmente arruínam aquilo que nem mesmo Dante ${ }^{59}$ leva às últimas consequências, ou seja, a identidade própria do danado (no sentido de individualidade, de personalidade), que tem a sua alma, feita à imagem e semelhança do seu corpo terreno, literalmente transformada, destroçada, impossível de se reconhecer. A ruína do corpo traduz a ruína da alma. E implica numa total perda de identidade, que como bem coloca Caroline W. Bynum ${ }^{60}$, ao comentar sobre a questão da metamorfose no Inferno de Dante dizendo que ele a emprega "de um modo que nos mostra a impossibilidade da perduração da identidade (em qualquer sentido lógico) sem a sobrevivência de vestígios do corpo ou do seu formato".

Acrescente-se a esse o outro suplício que Barlowe inventa, de extrema originalidade, por assim dizer, respeitante à compactação das almas danadas em tijolos vivos. Ele conta que teve essa ideia quando observava os blocos de automóveis após terem sido compactados por imensas prensas metálicas em ferros velhos $^{61}$. Consta no livro The Alien Life of Wayne Barlowe uma pequena ilustração que indica o processo de transformação das almas danadas em tijolos, mas os desenhos não são lá muito elucidativos ${ }^{62}$.

De qualquer modo fica a ideia terrível da nulidade a que essas almas ficam condenadas ao se transformarem em organismos cúbicos desfigurados, tijolos que sustentam paredes, espremidos entre uns e outros, como no Sheol hebraico em que "o esquecimento em que submergem é tão pavoroso que chegam a ser isentadas dos tormentos: consomem-se, fogo frio, na progressiva 
perda de identidade e no aniquilamento"63. Existe uma imagem literária antiga de conotação simbólica convergente ao do corpo tijolo de Barlowe. Consta na visão profética e apocalíptica intitulada 0 Pastor de Hermas $^{64}$, escrita entre os anos 136 e 145. Na sua evocação simbólica do Inferno, na visão III, Hermas vê seis jovens que constroem uma torre quadrada; entre as pedras que eles carregam, algumas são lançadas no fogo, outras rolam perto da água sem a alcançarem, outras ainda desaparecem em lugares inacessíveis. O ordenamento simbólico mostra a torre como a Igreja e as pedras como as almas danadas em suplícios diferenciados, de acordo com suas faltas. Um exemplo desse processo de incrustação e incorporação do corpo no edifício, consta numa ilustração de William Blake, feita para o Inferno de Dante ${ }^{65}$, onde os corpos dos danados são fossilizados, conformando as pontes sobre o poço infernal. As diferenças com o corpo tijolo de Barlowe, é que o corpo ponte de Blake, mantém sua forma permanente (os corpos se assemelham aos altosrelevos) e é inanimado.

Vale observar que o tijolo, no seu aspecto simbólico, representa a passagem da humanidade à vida sedentária e a origem da urbanização: casa, cidade e templo. Representa também o limite, “pois o tijolo significa a regra, a medida e a uniformidade. Será o início da sociedade fechada, em contraposição à sociedade aberta do nômade". ${ }^{66}$ Claro, visto que o Inferno de Barlowe, embora organizado por uma rígida e feroz hierarquia feudal, em termos da distribuição dos poderes, não evita o impulso civilizador e urbano típico das grandes sociedades, a exemplo da romana. O Inferno dos demônios arquitetos de Milton, construtores do belíssimo Pandemônio, perdura no de Barlowe, onde os demônios perpetuam sua história ao erigirem monumentos comemorativos da batalha contra o Céu. Mesmo que tenha sido derrotada, esta sociedade demoníaca não deixa de cumprir os ritos coletivos de veneração dos seus feitos heroicos, de ter orgulho da beleza da sua arquitetura, constantemente renovada, simbolizando uma necessidade cívica e urbana, e uma sede de cultura na sua estóica busca do permanente. E não é essa a história das grandes civilizações humanas?

Esse verdadeiro martírio da consciência, na perda da identidade do corpo, que os danados sofrem no Inferno de Barlowe, reflete uma relação simbólica problematizada entre a aparência corporal e a mente, numa atualidade "globalizada", repleta de contradições e diferenças sociais, como a que hoje se vive. Significativamente, não se trata mais aqui somente de uma tortura no sentido da dor física, limitada ao corpo, mas sim de um penoso processo de desintegração mental, onde nem mais é permitido ao danado o reconhecimento da sua identidade física anterior. Paródias da humanidade, andarilhos grotescos e mutilados, os danados do Inferno de Barlowe são almas que habitam corpos transformados, de identidades perdidas, onde não mais existe a memória da existência terrena e onde a história cessa de existir.

\section{Como diz David Le Breton ${ }^{67}$ :}

Se o homem só existe por meio das formas corporais que o colocam no mundo, qualquer modificação de sua forma implica outra definição de sua humanidade. Se as fronteiras do homem são traçadas pela carne que o compõe, suprimir ou acrescentar componentes modifica a identidade pessoal que é própria ao homem e suas referências aos olhos dos outros. Em suma, se o corpo é um símbolo da sociedade, como sugere Mary Douglas, toda modificação em sua forma afeta simbolicamente o vínculo social. Os limites do corpo desenham, em sua escala, a ordem moral e significante do mundo. Pensar o corpo é outra maneira de pensar o mundo e o vínculo social: uma desordem introduzida na configuração do corpo é uma desordem introduzida na coerência do mundo.

O ritual de punição dos danados recém-chegados prossegue com a inserção de esferas negras nos seus corpos, que passa a ser, de acordo com Barlowe, o único ponto comum entre eles. Essas esferas, que são socadas dentro dos recém-chegados por demônios especializados, flutuam livremente através dos corpos das almas, distorcendo-os enquanto se movem entre seus ossos e órgãos. Barlowe as concebeu como sendo ubíquas, tumorosas, pesadas, dolorosas e desconfortáveis, a lembrança constante do destino final dessas almas.

A concretização do termo mundo em imagens visuais costuma estar associada à representação da esfera, que, como figura de simetria por excelência, é um símbolo de ambivalência. Na tradição dos símbolos medievais, por exemplo, a esfera, enquanto orbe, o globo, significava o mundo, e, quando representada nas mãos do rei, indicava o poder, o domínio ou o território sobre o qual se estendia sua soberana autoridade. No Paraíso Perdido de Milton, o termo mundo designa ora o globo terrestre, ora o sistema solar, ora, finalmente, o complexo da Criação.

\footnotetext{
${ }^{63}$ COUSTÉ, Alberto. A Biografia do Diabo, Rio de Janeiro, Record, 1996, p. 64.

${ }^{64}$ MINOIS, George. História dos Infernos, Lisboa, Editorial Teorema, 1997, p. 91.

${ }^{65}$ TURNER, Alice. The History of Hell, New York, Harvest Book, 1995, p.139.

${ }^{66}$ CHEVALIER, Jean e Alain Gheerbrant. Dicionário dos Símbolos, Rio de Janeiro, José Olympio, 1998, p. 885.

${ }^{67}$ BRETON LE, David. In: Adauto Novaes, 0 Homem- Máquina: a ciência manipula o corpo, São Paulo, Companhia das Letras, 2003, p. 136
} 
Atendo-se ao sentido bíblico, de acordo com o que sustenta Delumeau, e também ao coincidente sentido medieval, a esfera no Inferno de Barlowe representa o mundo sob o domínio do Demônio. O Demônio Rei, senhor de todas as vastidões infernais e reino do mal absoluto.

Pode-se, ainda, atribuir outro sentido de ordem simbólica às esferas negras no Inferno de Barlowe. Conforme ele as descreve, elas são socadas nos corpos dos danados, neles se incorporando. São como, ele mesmo diz um câncer, um enorme tumor que lhes devora a carne na medida em que se movimentam. As esferas são para os danados a triste e constante lembrança dos motivos que os levaram ao Inferno, uma espécie de marca da consciência dilacerada pelo remorso dos pecados que conduz ao arrependimento, já sem nenhuma possibilidade de salvação. Isso possibilita relacionar estas esferas doentias e devoradoras do corpo com o verme que corrói por dentro, o mesmo verme roedor presente nos sermões do século XVIII, que ferirá continuamente o coração daqueles que pecam contra os princípios de Deus.

Observa-se que as cores cinza-pálidas com que Barlowe pinta os corpos de todos os danados, é característica do processo de resfriamento do magma vulcânico.

Barlowe diz que a maioria dos danados é de cor predominantemente pálida e que nenhum deles apresenta um tom mais carnal. Segundo ele, isto reflete a óbvia natureza necrótica da pele, embora não se limitando apenas ao cinza. Vê-se, então, que as esferas negras que flutuam nos corpos dos danados não são a única característica em comum entre eles. Quanto aos demônios, alguns poucos possuem essa cor, sendo a maior parte deles compostos de um magma escuro, com brasas ardentes no interior dos seus corpos, talvez simbolizando uma energia ativa, porém de natureza maléfica.

Sendo assim, os suplícios do Inferno de Barlowe retomam a punição pelo fogo, já que suas representações se ambientam no magma vulcânico que, inclusive, constitui a substância dos corpos dos danados (magma resfriado, daí a tonalidade cinza azulado, talvez indicando uma condição passiva) e dos demônios (chamas vivas e ardentes indicando talvez uma condição ativa). Relaciona-se também a febre convulsiva que agita o imenso corpo paisagem do Demônio, causando a constante inquietação do ambiente infernal.

${ }^{68}$ MORAES, Eliane Robert, O Corpo Impossível, São Paulo, Iluminuras, 2002, p.111.

${ }^{69}$ LALA, Marie-Christine. In: Moraes, Eliane Robert, O Corpo Impossível, São Paulo, Iluminuras, 2002, p. 197.
À concepção do corpo no Inferno de Barlowe, que remete ao projeto surrealista de extensão das vitalidades biológicas humanas aos seres vivos, todos movidos pela mesma "repugnância ao repouso"68, acrescenta-se uma capacidade para animar tudo na natureza, incluindo a paisagem e os edifícios, dotandoa daquela qualidade própria que distingue os homens dos animais no pensamento medieval, ou seja, a de possuir uma alma. No Inferno de Barlowe pode-se falar da onipresença carnal, do complexo medieval do corpus e da anima, impregnando a natureza como uma espécie de peste, dotando-a de uma atormentada, feroz e sofrida consciência, um pathos materializado, imperfeito, agônico, e, sobretudo, humano. O interessante aqui é que todo esse investimento na carne se faz pela utilização de partes do corpo que, em alguns significativos casos, se relacionam ao sagrado na simbologia medieval. O melhor exemplo disso está na representação do coração negro no portal de entrada do Inferno.

A imagem do homem, enquanto um composto de corpo e alma, reflete a mentalidade de uma época, com suas asserções e contradições, incluindo-se um imaginário próprio do corpo humano. Oscilando de uma visão platônica e cristã medieval, em que o corpo miserável é considerado apenas como o hábitat finito da alma imortal, passando por uma concepção materialista e idealizada de afirmação do corpo e de dissolução da alma, a partir do iluminismo, para a dissolução do próprio corpo na modernidade, parece não haver uma resolução para esse movimento pendular e contraditório. Antes, o que se percebe é a preservação da contradição entre as forças da vida e as forças da morte.

Marie Christine Lala afirma, a respeito do pensamento de Bataille, que a "a fusão é já dissolução, porque nela o sujeito se perde e se mantém ao mesmo tempo"69. A imagem acabada do homem, enquanto ser constituído de um corpo e de uma alma, numa perspectiva batailliana, nunca se fixa, pois a contradição da qual ela é formada sempre trabalha, jamais está em repouso. Assim como a que acontece nas representações dos corpos do Inferno de Barlowe.

$\mathrm{Na}$ contemporaneidade do Inferno de Barlowe a representação dos demônios volta a assumir características monstruosas, muito similares às da besta do medievo, demonstrando um aparente retorno às origens iconográficas do opositor de Deus. Digo aparente, porque na verdade os demônios concebidos por Barlowe fazem parte de um programa iconográfico de ilustração que objetiva o entretenimento de uma determinada faixa dos leitores norte-americanos, apreciadores do gênero fantástico e de ficção-científica, 
representada pelo público infanto-juvenil. A sua significação se dá nesse universo próprio da ficção, não só literária, mas também ilustrativa, em que as representações se ajustam ao imaginário e às expectativas desta faixa de leitores. O aspecto mais sofisticado diz respeito às correspondências simbólicas do Demônio com a paisagem do Inferno, na sua ligação física ao espaço cavernoso, onde ocorre de fato uma renovação das metáforas corporais renascentistas que integravam o corpo humano ao mundo.

O ecletismo religioso pretendido por Barlowe no seu Inferno apresenta uma dificuldade essencial na formulação das suas representações, visto que estas se referem a um vasto período histórico que se estende da Idade Média até a atualidade. As mudanças nas representações do Inferno neste período ocorreram em diferentes contextos históricos, em sociedades distintas, com significados diversos e que envolveram um complexo e diferenciado sistema de símbolos. Por detrás da sua intenção eclética, verifiquei que a ideia do Inferno cristão medieval era a que mais se fazia presente, embora destituída de um embasamento religioso mais aprofundado.

O dilema que certamente se apresentou a Barlowe na elaboração do seu Inferno é o de que uma representação dessa natureza, levada a sério, não pode ser convincente, num ponto de vista histórico, se não for amparada por um sistema religioso de base, ou de uma fé que a legitime. Eis a questão, e creio ter demonstrado que embora tenha procurado uma síntese das diversas religiões envolvidas, o sistema feito por Barlowe não resolveu a problemática. E nem poderia, pois, conforme se viu, desde o iluminismo, as representações do Inferno migraram para as temáticas bíblicas das tentações e da queda dos anjos, numa transferência simbólica em que se perdeu a relação do teológico com a imagem: daí o Inferno, refugiado na folia burlesca - de um Callot, por exemplo - e revestido de um sentido tão somente ficcional, desligouse do religioso e adentrou a modernidade sob a forma do grotesco individualizado.

A representação do Inferno de Barlowe retoma principalmente o aspecto do medo do Inferno medieval, mas não a sua subordinação ao Juízo Final, pois que ele, na sua concepção, não é precedido pelo julgamento divino. Não incluindo o Juízo, sua versão do Inferno carece de um sentido religioso. As almas danadas empreendem as suas penosas quedas desprovidas de um julgamento sem o qual o Inferno, como o lugar da punição eterna exemplar, perde a sua razão de ser. Sua ênfase de dá na ostentação dos demônios guerreiros, com seus atributos próprios do gênero capa e espada, imaginados sob medida para agradar o público infanto-juvenil, tradicionalmente afeito a essas representações. Neste aspecto, seu Inferno se conforma como um roteiro de um filme no qual os efeitos especiais contam muito mais do que a narrativa em si. Falta um embasamento teológico ao Inferno de Barlowe, pois que o mundo inferior é , em última instância, uma representação religiosa.

Barlowe acabou por representar um mundo alienígena de uma natureza subterrânea, similar ao interior da terra $^{70}$, dominado por extraterrestres (os demônios) que subjugam uma raça menor (os danados) e onde existe o grande organismo metamórfico vivo (o Demônio), que constitui o chão desse território imaginado e regido por uma "seleção natural" nos moldes darwinianos.

O Inferno foi, e continua sendo, uma invenção e uma necessidade do homem. Sua construção se deu na heterogeneidade dos tempos históricos e se fixou nas imagens da arte, inesquecíveis e exemplares da obsessão humana em se perscrutar nas representações do seu próprio corpo. É uma escolha do homem se colocar diante de si mesmo, de reconhecer aquelas dimensões interiores que conjugam, ou separam, o seu corpo do seu espírito, e de divisar o bem e o mal. Neste sentido, o corpo do homem se fez forma para representar simbolicamente o percurso histórico das suas crenças e da sua razão, e pelo que se viu, no tocante ao cristianismo, o corpo foi um receptáculo mutável e pronto a figurar as mais conflitantes representações, como a do Paraíso e a do Inferno. O corpo do homem soube, em alguns momentos na história, integrar matéria e espírito, corpo e alma, como na Grécia antiga, mas desde a proliferação do cristianismo no mundo, viu-se cindido por um dualismo arrebatador e imprescindível. Eis o grande paradoxo da cristandade, ter propagado um sistema religioso monoteísta que sempre necessitou de um dualismo de base, prontamente refutado pela teologia, mas que possibilitou a pregação da sua fé nas mais significativas representações da arte.

O Inferno contemporâneo existe e é um fato, fictício ou real. Seja no campo da imaginação, em que o homem se incendeia frente às suas impossibilidades e frustrações, ou na dura realidade dos acontecimentos cotidianos e hostis, com os quais é obrigado a conviver. Ao representá-lo na arte o homem se dá

\footnotetext{
${ }^{70}$ Embora Barlowe não cite Jules Verne como uma influência, ele certamente tem conhecimento da sua obra. O livro Journey to the Center of the Earth é uma das primeiras obras no gênero da ficção-científica, e guarda muitas semelhanças com a catábase de Barlowe ao Inferno. Jules Verne (18281905) foi um escritor francês, considerado por muitos como um dos fundadores da ficção-científica, expressou o espírito aventureiro e o fascínio acrítico com o progresso científico, característicos do século XIX.
} 
conta que as imagens do Inferno irão ocupar no seu espírito aqueles espaços profundos, enegrecidos, em que necessita se temer e, contrariamente à Narciso, reconhece no seu reflexo a besta interior.

\section{Fontes}

Fontes primárias impressas.

BARLOWE, Wayne. "Barlowe's Inferno". Galerie Morpheus International, Inc., Beverly Hills, 1998.

"Brushfire. Illuminations from the Inferno". Galerie

Morpheus International, Inc., Beverly Hills, 2001.

\section{Índice das Ilustrações}

O inferno ilustrado de Barlowe

Barlowe, Wayne Douglas. The molars of Leviathan. Beverly Hills: Morpheus, 1998.

"The wargate" in Barlowe's inferno. Beverly Hills: Morpheus, 1998.

"The examination" in Barlowe's inferno. Beverly Hills: Morpheus, 1998.

"The unholly communion" in Brushfire: Illuminations from the Inferno. Beverly Hills: Morpheus,2001.

MARTIN, John. The Fallen Angels Entering Pandemonium. Londres: Tate Gallery, 1840.
DORÉ, Gustave. A descida no monstro Gerião, Inferno. New York: Dover, 1976.

\section{Referências Bibliográficas}

BAXANDALL, Michael. "O Olhar Renascente. Pintura e Experiência Social na Itália da Renascença". Rio de Janeiro: Ed. Paz e Terra, 1991.

BYNUM, Caroline Walker. "Metamorphosis and Identity". New York: Zone Books, 2001.

CHEVALIER, Jean. “Dicionário de Símbolos”. José Olympio Editora, Rio de Janeiro, 1998.

COUSTÉ, Alberto. Biografia do Diabo. Rio de Janeiro: Ed. Record,1996.

MINOIS, Georges. História dos Infernos. Lisboa: Editorial Teorema, LDA, 1997.

MORAES, Eliane Robert. O Corpo Impossível. São Paulo: Editora Iluminuras Ltda, 2002.

NOCHLIN, Linda. The Body in Pieces. The Fragment as a Metaphor of Modernity. New York: Thames \& Hudson Inc.,1994.

NOVAES, Adauto. O Homem-Máquina: a Ciência Manipula o Corpo. São Paulo, Editora Schwarcz, 2003.

\section{A Contemporaneidade do Inferno Ilustrado de Barlowe}


